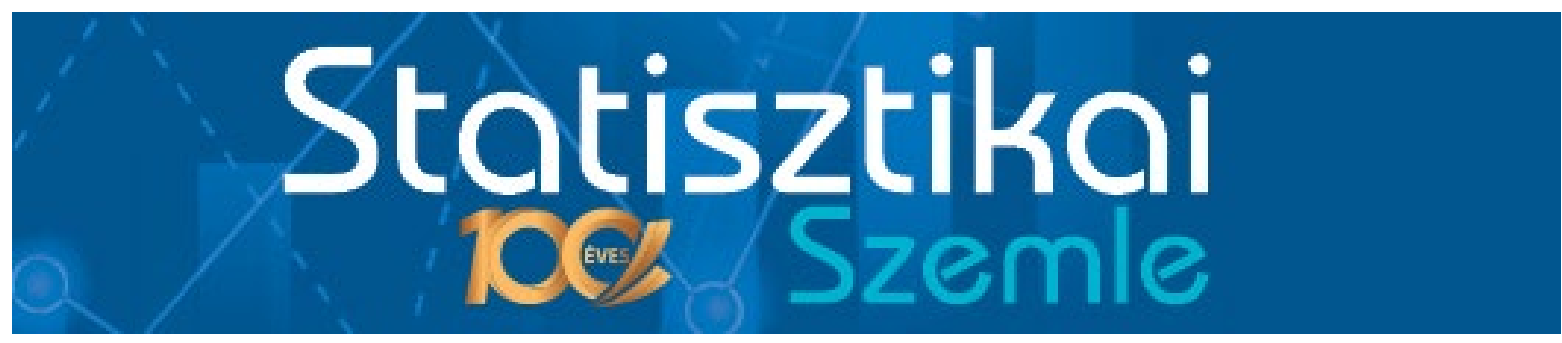

Közzététel: 2022. január 14.

A tanulmány címe:

A távorvoslás igénybevételét befolyásoló tényezők a COVID-19 járvány miatti félelem tükrében

Szerzők:

KEMÉNY ILDIKó,

a Budapesti Corvinus Egyetem egyetemi docense

E-mail: ildiko.kemeny@uni-corvinus.hu

Kulhavi Nikoletta Márta,

a Budapesti Corvinus Egyetem mesterhallgatója

E-mail: nikoletta.kulhavi@stud.uni-corvinus.hu

Kun ZSUZSANNA,

a Budapesti Corvinus Egyetem PhD-hallgatója

E-mail: zsuzsanna.kun@uni-corvinus.hu

DOI: https://doi.org/10.20311/stat2022.1.hu0007

Az alábbi feltételek érvényesek minden, a Központi Statisztikai Hivatal (a továbbiakban: KSH) Statisztikai Szemle c. folyóiratában (a továbbiakban: Folyóirat) megjelenő tanulmányra. Felhasználó a tanulmány vagy annak részei felhasználásával egyidejüleg tudomásul veszi a jelen dokumentumban foglalt felhasználási feltételeket, és azokat magára nézve kötelezőnek fogadja el. Tudomásul veszi, hogy a jelen feltételek megszegéséből eredő valamennyi kárért felelősséggel tartozik.

1. A jogszabályi tartalom kivételével a tanulmányok a szerzői jogról szóló 1999. évi LXXVI. törvény (Szjt.) szerint szerzői münek minősülnek. A szerzői jog jogosultja a KSH.

2. A KSH földrajzi és időbeli korlátozás nélküli, nem kizárólagos, nem átadható, térítésmentes felhasználási jogot biztosít a Felhasználó részére a tanulmány vonatkozásában.

3. A felhasználási jog keretében a Felhasználó jogosult a tanulmány:

a) oktatási és kutatási célú felhasználására (nyilvánosságra hozatalára és továbbítására a 4. pontban foglalt kivétellel) a Folyóirat és a szerző(k) feltüntetésével;

b) tartalmáról összefoglaló készítésére az írott és az elektronikus médiában a Folyóirat és a szerző(k) feltüntetésével;

c) részletének idézésére - az átvevő mü jellege és célja által indokolt terjedelemben és az eredetihez híven - a forrás, valamint az ott megjelölt szerzö(k) megnevezésével.

4. A Felhasználó nem jogosult a tanulmány továbbértékesítésére, haszonszerzési célú felhasználására. Ez a korlátozás nem érinti a tanulmány felhasználásával előállított, de az Szjt. szerint önálló szerzői münek minősülő mü ilyen célú felhasználását.

5. A tanulmány átdolgozása, újra publikálása tilos.

6. A 3. a)-c.) pontban foglaltak alapján a Folyóiratot és a szerző(ke)t az alábbiak szerint kell feltüntetni:

„Forrás: Statisztikai Szemle c. folyóirat 100. évfolyam 1. számában megjelent, Kemény Ildikó, Kulhavi Nikoletta Márta, Kun Zsuzsanna által írt, 'A távorvoslás igénybevételét befolyásoló tényezők a COVID-19 járvány miatti félelem tükrében' címü tanulmány (link csatolása)"

7. A Folyóiratban megjelenő tanulmányok kutatói véleményeket tükröznek, amelyek nem esnek szükségképpen egybe a KSH vagy a szerzők által képviselt intézmények hivatalos álláspontjával. 


\author{
Kemény Ildikó - Kulhavi Nikoletta Márta - Kun Zsuzsanna
}

\title{
A távorvoslás igénybevételét befolyásoló tényezők a COVID-19 járvány miatti félelem tükrében*
}

\section{Factors influencing the intention to use e-health in the light of fear of COVID-19}

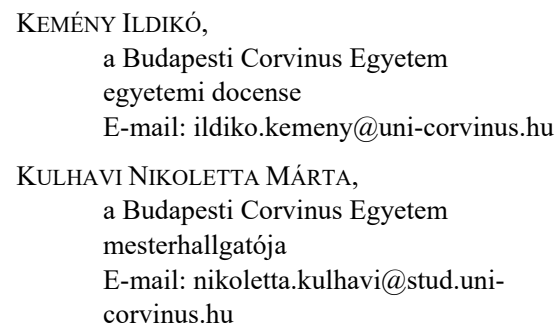

\author{
KUN ZSUZSANNA, \\ a Budapesti Corvinus Egyetem \\ PhD-hallgatója \\ E-mail: zsuzsanna.kun@uni-corvinus.hu
}

A magyar egészségügyben a 2000-es évek elején jelent meg a távorvoslás, amely a COVID-19 járvány kitörése óta dinamikus változáson megy keresztül. A szakemberek már közel egy évtizede vizsgálják az e-health-hez ${ }^{1}$ köthető használati szándékot technológiaelfogadási modellek segítségével, a szakmai ajánlások szerint azonban ezek bővítésére van szükség a jobb magyarázóerő elérése céljából. Jelen tanulmány célja, hogy a távorvoslással kapcsolatos teljesítményelvárásokat, használati szándékot és a tényleges használatot egy olyan kibővített PLS-PM-lel (partial least squares path model - parciális legkisebb négyzetek módszerével becsült útmodell) elemezze, amely konstrukcióként a COVID-19 járvány okozta félelmet, az online egészségügyi mủveltséget ${ }^{2}$, a technológiai jártasságot és a távorvoslás nyújtotta lehetőségek ismeretét tartalmazza. E módszer, megfelelve a mutatókkal és az eredmények bemutatásával kapcsolatos elvárásoknak, számos fejlesztésen ment keresztül az elmúlt időszakban. A szerzők ezeket az újításokat is ismertetik. Eredményeik alapján a távorvoslás elvárt teljesítményére a páciensek koronavírus miatti félelmének és technológiai jártasságának a hatása a legerősebb, de szignifikáns az online egészségügyi műveltségé és az e-health kínálta szolgáltatások ismeretéé is. A távorvoslásra vonatkozó

* Jelen tanulmány az Európai Unió, Magyarország és az Európai Szociális Alap társfinanszírozása által biztosított forrásból az EFOP-3.6.3-VEKOP-16-2017-00007 azonosítószámú „Tehetségből fiatal kutató A kutatói életpályát támogató tevékenységek a felsőoktatásban" címü projekt keretében jött létre.

${ }^{1}$ Írásunkban az e-health-et távorvoslásnak, illetve távegészségügynek nevezzük; e kifejezéseket szinonimaként használjuk.

${ }^{2}$ Az online egészségügyi müveltségen azt értjük, hogy az egyén képes internetes egészségügyi forrásokat keresni, értékelni, illetve döntéseit azokra építeni.

STATISZTIKAI SZEMLE, 100. ÉVFOLYAM 1. SZÁM 7-43. OLDAL DOI: 10.20311/stat2022.1.hu0007 
használati szándékot a páciensek teljesítményelvárásai befolyásolják leginkább. Az online egészségügy gyors és széles körü társadalmi elfogadásában az edukáció szerepe jelentős lehet.

KuLCSSZÓ: távorvoslás, COVID-19 járvány, PLS-PM

The COVID-19 epidemic has brought about a significant, dynamic change in the use of e-health, which emerged in the Hungarian healthcare in the 2000's. Technology adoption models have been investigating the intentions to use e-health for nearly a decade, but it is recommended that new factors be added to the model to achieve better explanatory power. The aim of this study is to estimate e-health performance expectations, intent to use, and actual use with an extended PLS-PM that also includes fear of COVID-19, online health literacy, IT skills and knowledge of ehealth. This method has recently undergone a number of improvements in terms of indicators and reporting requirements. The authors present these innovations, too.

Based on the results, it can be concluded that fear of the coronavirus and IT skills have the strongest effect on the expected performance of Internet medicine, but the impact of online health literacy and knowledge of e-health are also significant. The intention to use such healthcare practices is mostly affected by performance expectations. Education can play a significant role in the rapid and widespread adoption of these services.

KEYwORD: e-health, COVID 19 pandemic, PLS-PM

A digitalizációval, valamint az információs és kommunikációs technológia (IKT) fejlődésével párhuzamosan az e-egészségügyi szolgáltatások fogalma egyre szélesebb körben ismertté, igénybevétele pedig elterjedtebbé vált/válik, és e dinamikus folyamatot a COVID-19 járvány még fel is gyorsította/gyorsítja. Az eegészségügy amellett, hogy diagnosztikus eljárások, új terápiás módszerek alkalmazására és távfelügyeleti rendszerek használatára nyújt lehetöséget, egyben a hagyományos egészségügyi oktatási formák és betegségmegelőzést célzó szolgáltatások alternatívája is. Az egészségügyi ellátást magasabb színvonalúvá és egyben olcsóbbá, rugalmasabbá teszi.

Korábbi kutatások a távorvoslásra mint internetes egészségügyi ellátásra hivatkoznak (lásd például McLendon [2000]). Daragó et al. ([2013] 1168. old.) szerint ,,az ehealth (vagy e-health) a telehealthnek speciálisan az internet használatán alapuló szükítése (lásd: e-learning, e-commerce stb.)." Hasonlóan definiálja Eysenbach [2001] is a fogalmat, amikor interneten és más hasonló technológiákon keresztül nyújtott egészségügyi szolgáltatásként hivatkozik rá. Allen, Whitten és Maheu [2001] e-egészségügynek azokat az internetes alkalmazásokat nevezik, amelyek egészségüggyel és egészséggel kapcsolatos tartalmakat, klinikai ellátást és az

STATISZTIKAI SZEMLE, 100. ÉVFOLYAM 1. SZÁM 7-43. OLDAL DOI: 10.20311/stat2022.1.hu0007 
egészségügyi adatok összekapcsolhatóságát biztosítják. Tágabb értelmezésük szerint az e-egészségügy az interneten keresztül nyújtott ellátás minden formáját magában foglalja az információs, oktatási és kereskedelmi „termékektől” a közvetlen szolgáltatásokig (Allen-Whitten-Maheu [2001]). A magyar szóhasználatban az e-egészségügy és a távorvoslás elkülönül egymástól. Az előbbi inkább Allen, Whitten és Maheu 2001-es definíciójának felel meg, azaz az egészségügyi szolgáltatások mellett egészséges életmódhoz kapcsolódó online tájékoztatást és szolgáltatást is jelent. Ennél a távorvoslás jelentése szükebb, az Európai Bizottság megfogalmazása szerint (Európai Közösségek Bizottsága [2008]) egészségügyi szolgáltatások biztosítására korlátozódik olyan helyzetekben, amikor az egészségügyi dolgozó és a páciens nem azonos helyen tartózkodik. Ilyenkor sor kerül(het) betegségmegelőzést szolgáló, valamint a betegek diagnosztizálásához, kezeléséhez és állapotuk nyomon követéséhez szükséges egészségügyi adatok, információk biztonságos továbbítására is. Tanulmányunkban az e-health-et távorvoslásnak, illetve távegészségügynek nevezzük, és a fogalom alatt az online nyújtott egészségügyi szolgáltatások és információk összességét értjük (Eysenbach [2001], Pagliari et al. [2005]).

A távorvoslás lehetőséget teremt arra, hogy a betegek bármikor és bárhol kapcsolatba lépjenek az egészségügyi szolgáltatókkal (Butcher [2016]), és velük együtt releváns információkhoz férjenek hozzá (Kwankam [2004]). Az ilyen formában végzett gyógyító tevékenység során az egészségügyi szolgáltató által üzemeltetett betegportálok mint kommunikációs csatornák müködnek, elektronikus orvosi dokumentumok, digitális egészségügyi információk továbbítására kerül sor, a szakszemélyzet jelenlétét pedig hordható, illetve távfelügyeleti eszközök pótolják (Peng-DeyLahiri [2014]). Az ellátás javítására és a betegek bevonására nagy figyelmet fordító távegészségügyi rendszerekben a hagyományos orvoslásnál fontosabb szerepet töltenek be a digitális eszközök (Dahl-Milne-Peltier [2019], Lupton [2013]). A számítógépes alkalmazások e célt szolgáló tervezésekor elsődleges szempont, hogy azok megfeleljenek az egészségügyi információtartalomra vonatkozó előírásoknak, és egyszerü hozzáférést biztosítsanak olyan felhasználók, többek között idős betegek számára, akik nem rendelkeznek széles körü számítógépes tapasztalatokkal (DemirisFinkelstein-Speedie [2001]).

A távorvoslás által a (munkaerő- és egyéb) költségek csökkenthetők, illetve lehetőség nyílik az öngondoskodásra (a medikai eszközök alkalmazása a betegek által könnyen elsajátítható). További előnye, hogy bárki számára könnyen elérhető (a modern társadalmakban az idős emberek nagy részének is van internethozzáférése; Arief-Hai-Saranto [2013]), segít kiküszöbölni a hosszas várakozásokat és csökkenteni az orvos-beteg kontaktusok számát (ami a COVID-19 járvány idején kiemelten fontos szempontnak tekinthetö), illetve egyszerü hozzáférést biztosít a beteg állapotát leíró információkhoz (Daragó et al. [2013]). Pinzon-Perez és Zelinski [2016] szerint az egészségügyi ellátások igénybevételében létfontosságú segítséget nyújt a 
félreeső helyeken élők számára. A távorvoslás hátrányai közé sorolható ugyanakkor az IKT-hálózatok és az adatbázisok összetettsége, az egészségügyi problémák kezelésének esetenkénti hosszabb ideje (Arief-Hai-Saranto [2013]), az orvos-beteg közötti személyes kapcsolat gyengülése, valamint a személytelenség miatt sokszor kialakuló páciensi bizalmatlanság (Daragó et al. [2013]). Ezeken túl kihívást jelenthet az adatvédelem biztosítása is. E korlátok ellenére a távorvoslás várhatóan fontos szerepet tölt majd be a jövőben, amit a digitális technológia és a mesterséges intelligencia fejlödése is elősegít.

A távegészségügy ugyan hazánkban is évek óta müködik, elterjedése mégis - a világtendenciához hasonlóan - a COVID-19 járvány miatt gyorsult fel. Ehhez kapcsolódva, célunk egy olyan modell megalkotása volt a korábbi kutatási eredmények felhasználásával, amellyel a páciensek jellemzőinek, attitüdjének tükrében meghatározhatók a távorvoslással kapcsolatos teljesítményelvárások és használati szándék. Modellünk újdonsága, hogy a korábban vizsgált technológiai szorongás változó helyett a COVID-19-től való félelmet mint lehetséges „motivációs” tényezőt tartalmazza, valamint a klasszikus technológiaelfogadási magyarázó változók mellett olyan új tényezők hatását is elemzi, mint az online egészségügyi műveltség és a távorvoslás ismerete. A technológiaelfogadási modellek (technology acceptance model, TAM) ilyen irányú fejlesztése a szakirodalom által is megfogalmazott elvárás (Yarbrough-Smith [2007], Bahlol et al. [2018]).

Tanulmányunkban először a pandémia orvos-beteg kapcsolatra gyakorolt hatását mutatjuk be, majd a kutatási keretrendszerünk alapjául szolgáló TAM-eket tekintjük át először általánosságban, később a távorvoslásra szükítve. Ezt követően az elemzésünkben használt PLS-PM-módszertan újdonságaiba engedünk bepillantást, és megfogalmazzuk hipotéziseinket. A 3. fejezetben vizsgálatunk eredményeit tárgyaljuk, végül megállapításainkat, következtetéseinket ismertetjük.

\section{Szakirodalmi áttekintés}

\subsection{A távorvoslás és a COVID-19 járvány}

A koronavírus-járvány átalakította az orvos-beteg kapcsolatot. A pandémia alatt egyre több egészségügyi intézmény kezd(ett) el használni különféle távorvosláshoz kapcsolódó eljárásokat, melyek nemcsak a betegség terjedésének ellenőrzésében, de a szociális távolságtartás idején nyújtott betegellátásban és a fertőzésveszély csökkentésében is hasznosnak bizonyulnak/bizonyultak (Julesz [2020]). Egyes kórházak, mivel a fertőzés kockázatának csökkentése érdekében be kellett, hogy zárják

STATISZTIKAI SZEMLE, 100. ÉVFOLYAM 1. SZÁM 7-43. OLDAL DOI: 10.20311/stat2022.1.hu0007 
kapuikat bizonyos betegek előtt, megpróbálták a személyes orvos-beteg kapcsolatot digitális terápiával helyettesíteni (Wind et al. [2020]). Ez a betegek és családtagjaik, valamint az egészségügyi szolgáltatók számára egyaránt megfelelő megoldást jelent(het) (Zhou et al. [2020]). A virtuális alapellátás lehetővé teszi például a COVID-19 enyhe eseteinek biztonságos kezelését, és segíti a páciensek tájékoztatását. A betegség fizikai tünetei mellett azonban fel kell ismerni a járvány okozta pszichés reakciókat is (Shigemura et al. [2020]). Ez utóbbiak tekintetében szintén hasznosnak bizonyulnak az e-egészségügyi rendszerek, mivel biztosítják a kórházban vagy otthon karanténban levő, esetleg súlyos tüneteket mutató páciensek folyamatos társadalmi kapcsolattartását (például orvosaikkal vagy más betegekkel) (PappotTaarnhøj-Pappot [2020]).

A távegészségügy a koronavírus-szimptómák csökkentésében is jelentős szerepet játszhat (Hollander-Carr [2020]). Ting et al. [2020] a járvány terjedésének nyomon követésében, megfigyelésében és a betegség felderítésében betöltött funkcióját emelik ki. A pandémia leküzdése érdekében világszerte számos távegészségügyi szolgáltatás indult, melyek COVID-szürésre és a betegek távfelügyeletére egyaránt alkalmasak (Pappot-Taarnhøj-Pappot [2020]). Tsion és Tebeje [2020] megállapítják, hogy az internet, a különféle e-egészségügyi (és ezen belül telemedicina-) megoldások, valamint az elektronikus egészségügyi nyilvántartások nemcsak a betegközpontú egészségügyi ellátás megteremtését támogatják, de könnyen felhasználhatók a világjárvány visszaszorítására is. Azok a digitális megoldások, amelyek a betegek igényeire és mindennapos tevékenységeire (például digitális vércukorszintmérés, vérnyomás-ellenőrzés, aktív mozgással töltött idő mennyisége) összpontosítanak, alapjaiban változtathatják meg a betegellátást és az egészségügyi szolgáltatások igénybevételének eddigi formáit.

Az egészségügy tehát a ,szemünk elött” alakul át, és e folyamatot a COVID-19 járvány jelentősen fel is gyorsítja. Incze és Pesuth [2020] szerint a távorvoslás különösen azon országok egészségügyi ellátórendszerének megújításában kaphat nagy szerepet, és teheti könnyebbé az ilyen jellegü szolgáltatásokhoz való hozzáférést, ahol az egészségügy alulfinanszírozott, infrastruktúrája nem megfelelö, és az információk könnyü elérhetősége nem biztosított.

\subsection{A technológiaelfogadási modellek áttekintése}

A gyorsuló ütemü digitalizáció és technológiai fejlödés következtében a felhasználói (fogyasztói) elfogadás és adaptáció régóta a kutatások fókuszában áll. Számos esetben ugyanis problémát jelent, hogy a felhasználók nem tudják, vagy nem akarják (ki)használni a rendelkezésre álló IKT-alkalmazásokat, digitális eszközöket és az azok nyújtotta lehetőségeket. E kihívás felmerülhet a távorvoslás elfogadása, igénybevétele vonatkozásában is.

STATISZTIKAI SZEMLE, 100. ÉVFOLYAM 1. SZÁM 7-43. OLDAL DOI: 10.20311/stat2022.1.hu0007 
A technológiahasználattal kapcsolatos felhasználói (fogyasztói) elfogadás és viselkedés előrejelzésének, illetve értékelésének egyik legismertebb eszköze (Hu et al. [1999]) a TAM, melyet Fred Davis fejlesztett ki 1986-ban, és erös prediktív ereje miatt mára közkedvelt eljárássá vált (Yarbrough-Smith [2007]). A TAM-re épülő vizsgálatok eredményei szerint az emberek akkor hajlamosabbak elfogadni és használni egy új technológiát, ha az elfogadó magatartás nem igényel tőlük jelentős energiabefektetést, és az újítás javítja a teljesítményüket (Wallace-Sheetz [2014]). E modellel az is megállapítható, hogy mely tényezők befolyásolják az innovációk átvételének folyamatát (Borges-Kubiak [2016]).

Davis, Bagozzi és Warshaw [1989] a TAM-et módosítva és kiegészítve alkották meg a TAM1-t, amelynek középpontjában a technológiahasználat iránti attitüd, a használati szándék és a tényleges használat állnak (Keszey-Zsukk [2017]).

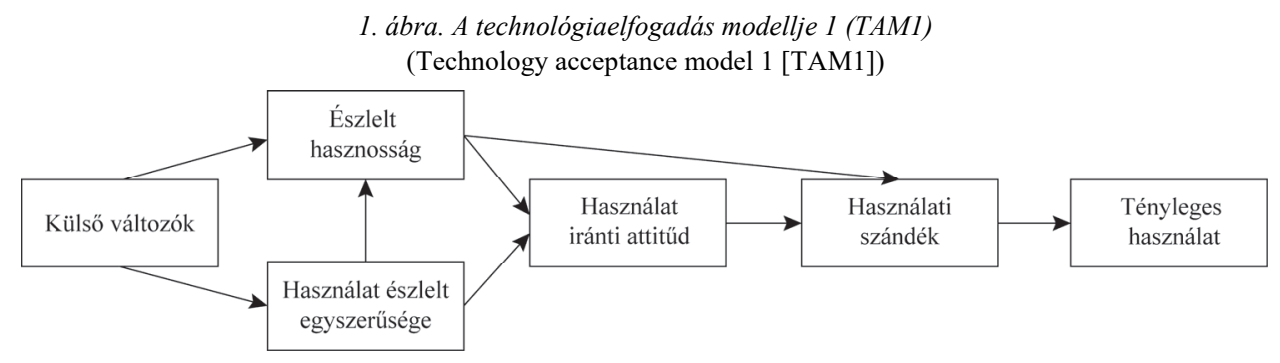

Forrás: Davis-Bagozzi-Warshaw [1989].

A TAM szerint az egyének percepciójának legfontosabb tényezői az észlelt hasznosság és a használat észlelt egyszerüsége a technológiahasználatra irányuló viselkedési szándékot tekintve (Wilson-Lankton [2004]). Keszey és Zsukk [2017] munkájából kiderül, hogy a modell külső (független) változói nem befolyásolják közvetlenül a fogyasztók attitüdjét, viselkedését, az észlelt hasznosságot és a használat észlelt egyszerüségét viszont igen. Külső változók lehetnek például a technológiai innovációk, illetve a felhasználók sajátosságai. Az észlelt hasznosság azt fejezi ki, hogy ,az egyén mennyire gondolja úgy, hogy az adott rendszer használata javítja saját teljesítményét" (Davis-Bagozzi-Warshaw [1989] 320. old.). A használat észlelt egyszerüsége pedig arra utal, hogy „,az illető mennyire tekinti a rendszer használatát erőfeszítéstől mentesnek" (Davis-Bagozzi-Warshaw [1989] 320. old.), más szóval milyen mértékủ mentális és fizikai erőfeszítést kell kifejtenie annak igénybevételéhez (Keszey-Zsukk [2017]). Egy technológia észlelt hasznosságát a használat észlelt egyszerüsége közvetlenül befolyásolja, mivel „minél könnyebb azt használni, annál hasznosabb lehet" (Davis-Bagozzi-Warshaw [1989] 320. old.). Az észlelt hasznosság és egyszerüség pedig hatással van a használat iránti attitüdre, amelyet a használati szándék és a tényleges használat követ (Keszey-Zsukk [2017]). 
A TAM1 továbbfejlesztéseként jelent meg a TAM2, amelyet Venkatesh és Davis dolgozott ki [2000]. Szükség volt ugyanis egy olyan modellre, amely elődjénél jobb magyarázóerővel rendelkezik, valamint figyelembe veszi a technológiai változások indukálta társadalmi hatásokat, például a szubjektív normákat (tehát azt, hogy az egyén környezete mit gondol a technológiai eszköz használatáról) (Keszey-Zsukk [2017]). A TAM2 valójában az eredeti TAM módosított változata, amelyben az „attitüdök” koncepciója helyett a társadalmi befolyásolás szerepel (Venkatesh-Davis [2000]). A TAM2-t longitudinális kutatásokban tesztelve, Legrisa, Inghamb és Collerettec [2003] megállapítják, hogy az a rendszerhasználat változó varianciájának mintegy 40 százalékát magyarázza. A TAM2 sokkal részletesebben vizsgálja az észlelt hasznosságra ható külső, valamint azon tényezőket, amelyek közvetlenül vagy moderátorváltozóként befolyásolják a használati szándékot. A modell új elemeinek két nagy csoportja van: társadalmi befolyásoló és kognitív koncepciók. Az elöbbiek közé tartozik például a szubjektív norma, az önkéntesség és az imázs, míg az utóbbiakhoz a munkához való illeszkedés (job relevance), a kimenet minősége és az eredmény láthatósága.

Mivel a technológiai eszközök felhasználói felülete idővel egyszerübbé vált, a TAM2-t kiterjesztették az észlelt könnyü használatot meghatározó tényezőkre, és megszületett a TAM3 (Venkatesh-Bala [2008]). E tényezők is két csoportra oszthatók: az ún. „,viselkedési horgonyokra”, amelyek korábban szerzett általános tapasztalatokból származnak (például technikai énhatékonyság, észlelt külső kontroll, technológiai szorongás, technológia játékossága), illetve a korrekciós tényezőkre (észlelt élvezeti érték, objektív használhatóság) (Keszey-Zsukk [2017]).

A TAM-ek közé tartozik a technológiaelfogadás és -használat egységesített elmélete (unified theory of acceptance and use of technology, UTAUT; Venkatesh et al. [2003]) is. Ezzel a menedzserek által használható, praktikus eszközzel megbecsülhetö az új technológiák bevezetéséhez füzött siker valószínüsége. $\mathrm{Az}$ UTAUT jól alkalmazható és értelmezhető munkahelyi környezetben. Venkatesh et al. [2003] a következö nyolc elméletet integrálták az UTAUT-ba: logikus cselekvések elmélete, tervezett viselkedés elmélete (TPB), TAM, motivációs modell, TAM-et és TPB-t kombináló modell, személyi számítógép használatának modellje, Rogers-féle diffúziós elmélet és társadalmi kognitív elmélet. Ezeken túl megjelenik benne négy használati szándékot és tényleges használatot befolyásoló (várható teljesítmény, várható szükséges erőfeszítés, társadalmi hatás és elősegítő feltételek), illetve négy moderáló tényező (nem, életkor, tapasztalat és a használat önkéntessége) is (Venkatesh et al. [2003]). Továbbfejlesztett változata az UTAUT2-modell, amelynek célja a hétköznapi használatra alkalmas technológiák várható elfogadásának mérése. Ez már nem tartalmazza az önkéntességi tényezöt, viszont három új aspektust magában foglal: hedonista motiváció, ár-érték, szokás (Keszey-Zsukk [2017]). 


\subsection{Technológiaelfogadási modellek alkalmazása a távorvoslás vizsgálatában}

A világméretű online informatikai infrastruktúrák gyors fejlődése következtében a TAM-et sokak által elismert robusztussága és prediktív ereje miatt először az internetes alkalmazások és szolgáltatások felhasználók általi elfogadásának elemzésére használták (Venkatesh-Davis [2000], Pavlou [2003]). Ezt követően azonban kiterjesztették az egészségügyi szektor információs rendszereire is (Bahlol et al. [2018]), ahol széles körben vesznek igénybe új technológiákat a szolgáltatások minőségének folyamatos javitása érdekében (Blackwell-Gordon [2008]). Ezáltal a modell alap- és kibővített változatai megjelentek a távorvoslás, illetve az ahhoz kapcsolódó kommunikációs rendszerek használatát magyarázó kutatásokban is (például Novak-Hoffman-Adam [2003], Yarbrough-Smith [2007]). Ezek a vizsgálatok elsősorban a távorvoslás különféle alkalmazásaira (Wilson-Lankton [2004]), illetve egyéb egészségügyi információs rendszerekre összpontosítanak, és a TAM segítségével a betegek online egészségügyi szolgáltatásokkal összefüggő viselkedését tanulmányozzák (Ahlan-Ahmad [2015]), azonosítva az IKT igénybevételét befolyásoló tényezőket (Garavand et al. [2016]). Bahlol et al. [2018] szisztematikus áttekintést adnak a TAM alap- és kibővített változatainak használatáról, rámutatva, hogy a távegészségügyi kutatások főként a teleegészségügyet, az elektronikus egészségügyi nyilvántartást és a mobil alkalmazásokat helyezik górcső alá.

Az első TAM-re épülö, távorvoslással foglalkozó kutatás az orvosok technológiabevezetési szándékának elemzésére fókuszált (Hu et al. [1999]); Cranen et al. [2011] pedig a páciensek webalapú távegészségügyi szolgáltatásokkal kapcsolatos véleményét elemezték. Abdullah et al. [2016] a modell segítségével azt vizsgálják, hogy a betegek mennyire fogadják el a vérnyomás otthoni nyomon követésére szolgáló, alapellátás keretében nyújtott távfelügyeleti szolgáltatást. Néhány kutató (például Holden-Karsh [2010]) felhívja a figyelmet arra, hogy a TAM nem képes megragadni a távorvoslás egyedi kontextusbeli jellemzöit, mivel azt nem kifejezetten az egészségügyi környezetre fejlesztették ki. A bázismodellben csak két változó szerepel a viselkedési szándék meghatározására (Cho-Kim-Kim [2010]), tehát konstrukciói nem veszik figyelembe a távorvoslás rendszerének használati összefüggéseit (Liu [2010]). Ezért a TAM kiterjesztésére és további konstrukciók beépítésére van szükség annak érdekében, hogy a magyarázóereje javuljon (HoldenKarsh [2010]). Egyes szerzők így elsősorban a TAM kibővített változatait használják a távorvoslási IKT-alkalmazások elfogadásának és a szervezeti folyamatok elemzésekor (Bahlol et al. [2018]). A prediktív erö növelése érdekében ugyanakkor egyre több kutatásban egészítik ki ezeket olyan kontextualizált koncepciókkal, mint a meggyőződés kiváltása, ami által a TAM már illeszkedni tud az e-health-ben használt IKT összefüggésrendszeréhez (Yarbrough-Smith [2007]). 
Liu, Caelli és Chen [2013] dolgozatukban a webes egészségügyi nyilvántartási rendszer használatát tanulmányozzák TAM segítségével, melybe az orvos-beteg kapcsolat konstrukciót integrálták. Lai et al. [2008] egy, a TAM2 alapján tervezett új keretrendszer, az ún. személyre szabott beavatkozások depressziós tünetek kezelésére elnevezésű program (tailored interventions for management of depressive symptoms, TIDES) páciensek általi elfogadását vizsgálják a szubjektív norma, munkához való illeszkedés és tapasztalat konstrukciókat szociodemográfiai, korrekciós, illetve munkához való illeszkedés látens változókra cserélve. Gagnon et al. [2012] szerint a TAM elemei közül az észlelt hasznosság és a használat észlelt egyszerüsége bizonyul a távegészségügy elfogadását leginkább befolyásoló tényezőknek. Wilson és Lankton [2004] a páciensoldali belső motivációt, viselkedési szándékot és külső motivációt, valamint az e-health észlelt könnyü használatát és észlelt hasznosságát mérve megállapítják, hogy az integrált elfogadási modellek jól teljesítenek a betegek távorvoslási szolgáltatásokkal kapcsolatos használati szándékának elörejelzésében. Jung és Loria [2010] mélyinterjúk során adott válaszok alapján, TAM segítségével vizsgálják a svéd online egészségügyi szolgáltatások elfogadását meghatározó tényezőket. Véleményük szerint az egyéni technológiaelfogadás legmeghatározóbb tényezői az észlelt hasznosság és a bizalom.

Az előbbiekben hivatkozott tanulmányok bizonyítják, hogy az észlelt hasznosság és a használat egyszerüsége kulcsfontosságú tényezők a távorvoslás elfogadásában. Mint korábban említettük, az általunk kidolgozott modell újdonsága és hozzáadott értéke, hogy a korábban vizsgált technológiai szorongás változó helyett a COVID-19-től való félelmet mint lehetséges motivációs tényezőt tartalmazza, és a klasszikus technológiaelfogadási magyarázó változók mellett olyan új tényezők hatását is elemzi, mint az online egészségügyi müveltség és a távorvoslás ismerete.

\section{Alkalmazott módszertan és kutatási hipotézisek}

\subsection{A PLS-PM módszertana}

A PLS-PM a SEM-ek közé tartozik, melyek lehetőséget nyújtanak a közvetlenül nem mérhető fogalmak, az ún. látens változók közötti kapcsolatok modellezésére. Fornell [1982] szerint a többváltozós elemzések második generációjának számítanak. Két típusukat különböztetjük meg: a kovariancia- (covariance-based SEM, CB-SEM) és a varianciaalapú SEM-eket (PLS-SEM/PLS-PM) (Nagy et al. [2019], Benitez et al. [2020]). 
E módszertan gazdálkodástani kutatásokban való jelentőségét bizonyítja, hogy 2016 és 2020 között a Statisztikai Szemle hasábjain összesen kilenc olyan publikáció jelent meg, amelyek a SEM-ek használatát tárgyalják; ezek közül négy esetben varianciaalapú PLS-PM-t választottak a szerzők (Kun-Kulhavi-Kemény [2021]). Ezek népszerüségét az indokolja, hogy alkalmasak elméleti konstrukciók közötti kapcsolatok modellezésére és becslésére, teljes elméletek tesztelésére, miközben képesek könnyen átlátható grafikus ábrázolási megoldást is nyújtani (Henseler [2021]).

A korábbi kritikák és észrevételek által előmozdítva, az elmúlt években a PLS-PM-módszertan számos fejlesztésen esett át, így ma már ,érett” modellezési módszernek számít. Lényegét több hazai tanulmány is tárgyalja (Kazár [2014]; Kemény [2015], [2017]; Nagy et al. [2019]; Aranyossy-Recskó [2021]), ezért mi csak az elmúlt évek fejlesztéseire, a manifeszt változók $\mathrm{k}^{3}$ lehetséges új szerepkörére, a konzisztens PLS-algoritmusra, valamint a riportkészítéshez kapcsolódó elvárásokra koncentrálunk. Leírásunkkal a módszertan legújabb alkalmazási lehetőségeire és az ezekkel kapcsolatos javaslatokra, elvárásokra (Henseler [2017], Benitez et al. [2020]) szeretnénk felhívni a figyelmet. Az általunk használt legfontosabb fogalmak angol és magyar megfelelőjét, valamint rövid értelmezésüket a 2. táblázat foglalja össze a 2.4. alfejezetben.

\subsection{A manifeszt változók új szerepköre}

Korábbi elemzésekben a megfigyelt (manifeszt) változók előzmény- vagy következményváltozókként szerepelnek, ami alapján oksági-formatív és reflektív mérési modellek különböztethetök meg (Kazár [2014]). A reflektív mérési modellek grafikus megjelenítésekor a nyíl a látens változótól mutat az indikátor irányába, ezzel is jelezve, hogy a megfigyelt változó a fogalom következményeként értelmezhető. Ezzel szemben az oksági-formatív mérési modellek esetében, amikor a manifeszt változók a mért konstrukció előzményei, fordított az irány. Mindkét esetben igaz azonban, hogy az elméleti koncepciók közvetlenül nem mérhetők, a manifeszt változókból egy matematikai modell segítségével lehet rájuk következtetni. Ezeket a statisztikai változókat, melyek tehát a koncepciók absztrakt megjelenítései, nevezi a szakirodalom hagyományosan látens változóknak. Az indikátorok és a konstrukciók között az összekötő elmélet (auxiliary theory) az elméleti kapocs, amely a koncepciók operacionalizálását teszi lehetővé (Henseler [2021]). Látens változók esetében a méréselmélet szolgál segítő elméletként, amely a közös ok (common cause) elvén alapszik. Ennek értelmében az elméleti koncepciót a megfigyelt változók és azok összefüggései adják (Reichenbach [1956], Füstös [2009]).

\footnotetext{
${ }^{3}$ A tanulmányban a manifeszt/megfigyelt változókat és az indikátorokat szinonimaként használjuk.
} 
Henseler [2017] azonban felhívja a figyelmet arra, hogy léteznek olyan koncepciók is, amelyeknél a manifeszt változók nem a konstrukciók okai vagy okozói; ehelyett közösen hozzák létre a konstrukciókat (a szakirodalom létrehozott [emergent/forged] változókként hivatkozik rájuk). Ebben az esetben tehát nem oksági kapcsolatot feltételezünk, hanem inkább egy definiált modellt. Összekötő elméletként ilyenkor a szintetizáló elmélet (synthesis theory) szolgál, amely szerint a megfigyelt változók (komponensek) alkotják az elméleti koncepciót; és megkülönböztetésük a látens változóktól az ún. kompozit mérési (faktor-) modell alapján történik (Henseler [2021]).

Henseler [2017] a konstrukciók kifejezés használatát javasolja a látens és létrehozott változók közös elnevezéseként. Az utóbbiak újfajta operacionalizálási lehetőséget jelentenek olyan koncepciók esetében, amelyeknél nem az előzmények vagy következmények, hanem az alkotóelemek, komponensek mérésére van lehetőség. A létrehozott változók jellemzően emberekhez vagy vállalatokhoz köthetők (például teljesítmény, attitüd), tehát a természetben magukban nem léteznek, ezért is szoktak rájuk „artifakt” (müalkotás/mütermék) kifejezéssel hivatkozni (Henseler [2017] 178. old.). Mivel a gazdálkodástani kutatások esetében is találkozhatunk ilyen fogalmakkal (például vállalati vagy üzleti folyamatok teljesítménye, közösségi média, IT-képesség), érdemes a jövőben ezzel a mérési modellel is részletesebben megismerkedni.

1. táblázat

A mérési modellek típusai

(Types of measurement models)

\begin{tabular}{|c|c|c|c|}
\hline Jellemző & $\begin{array}{l}\text { Kompozit } \\
\text { mérési modell }\end{array}$ & $\begin{array}{l}\text { Reflektív } \\
\text { mérési modell }\end{array}$ & $\begin{array}{c}\text { Oksági-formatív mérési } \\
\text { modell }\end{array}$ \\
\hline $\begin{array}{l}\text { Indikátor és konstrukció } \\
\text { kapcsolata }\end{array}$ & $\begin{array}{l}\text { Alkotóelem, rész, komponens; } \\
\text { az indikátorok hozzák létre } \\
\text { a konstrukciót }\end{array}$ & $\begin{array}{l}\text { Következmény; } \\
\text { a konstrukció következ- } \\
\text { ményei az indikátorok }\end{array}$ & $\begin{array}{l}\text { Előzmény, ok; } \\
\text { az indikátorok okoz- } \\
\text { zák a konstrukciót }\end{array}$ \\
\hline Konstrukció típusa & Létrehozott változó & Látens változó & Látens változó \\
\hline $\begin{array}{l}\text { Megfigyelt változók } \\
\text { közötti korreláció }\end{array}$ & $\begin{array}{l}\text { Jellemző, de nem elvárt a } \\
\text { magas korreláció }\end{array}$ & Elvárt a magas korreláció & \begin{tabular}{|l} 
Nem feltételezhető \\
korreláció
\end{tabular} \\
\hline Mérési hibára való hajlam & Tartalmazhat mérési hibát & Tartalmaz mérési hibát & $\begin{array}{l}\text { Tartalmazhat mérési } \\
\text { hibát }\end{array}$ \\
\hline $\begin{array}{l}\text { Egy indikátor elhagyásá- } \\
\text { nak következménye }\end{array}$ & $\begin{array}{l}\text { Megváltoztatja a létrejövő } \\
\text { változót, és módosíthatja } \\
\text { annak jelentését is }\end{array}$ & $\begin{array}{l}\text { Nem változtatja meg a } \\
\text { látens változó jelentését }\end{array}$ & $\begin{array}{c}\text { Konstrukció szintjén } \\
\text { megnöveli a hiba- } \\
\text { előfordulás esélyét }\end{array}$ \\
\hline
\end{tabular}

Forrás: Henseler ([2017] 180. old.). 
A mérési modellek esetében a Likert-skálás vagy a szemantikus differenciálskálás felmérések az elfogadottak, sőt bizonyos esetekben nominális változók használata is lehetséges. Ha egy kategorikus változónak csak két kimenete (szintje) van (dichotóm változó), akkor közvetlenül konstrukciós változóként szolgálhat; ha viszont kettőnél több, akkor dummy változóvá alakítandó. Ebben az esetben az $n-1$ dummy változó (ahol $n$ a szintek/kimenetek számát jelöli) mint indikátor jelenik meg a kompozit modellben, a fennmaradó 1 pedig referenciaszintként szolgál. A kategorikus változókat lehetőség szerint csak exogén (magyarázó/független) pozícióban javasolt használni a SEM-ben (Henseler et al. [2016]). Dummy változók esetén a strukturális modell megrajzolása hatszög formában ajánlatos a szokásos ovális helyett (Henseler [2021]).

\subsection{A konzisztens PLS}

A hagyományos PLS-PM alkalmazásának reflektív mérési modellek esetében megvannak a maga korlátai: a megfigyelt és a látens változók közötti faktorsúlyok felülbecsültek, a látens változók közötti utak pedig torzítottak (Gefen-RigdonStraub [2011]). E torzítások a hipotézisvizsgálat eredményeit is befolyásolják, és a módszer statisztikai ereje csökken a szignifikáns hatások felderítése során (DijkstraHenseler [2015]). Amennyiben a valós értéket a módszer alulbecsüli, másodfajú hiba jöhet létre (hamis negatív eredmény; elfogadjuk a nullhipotézist, bár az nem teljesül), míg, ha túlbecsüli, elsőfajú hiba (hamis pozitív eredmény; elvetjük a nullhipotézist, noha teljesül). A kutatóknak a hagyományos PLS-módszer alkalmazásakor tisztában kell lenniük ezekkel a korlátokkal, és olyan megközelítést kell alkalmazniuk, amely azokat mérsékli, és a torzítást csillapítja. Erre kínál megoldást például a konzisztens PLS módszertana (PLSc) (Dijkstra-Henseler [2015], AranyossyRecskó [2021]). Ennek használatakor a tradicionális PLS-algoritmus által képzett eredményeket a Dijkstra-Henseler-féle $\rho_{\mathrm{A}}$-val korrigálva futtatják le, konzisztens értékeket hozva létre. Az így kapott eredmények már összehasonlíthatók a kovarianciaalapúakkal (például az AMOS-programmal becsültekkel). Hasonlóan a CB-SEMhez, a PLSc is csökkenti az első- és másodfajú hiba valószínüségét, amely előfordulhat a hagyományos PLS-nél a reflektív mérési modellek használatakor és a regreszsziónál. A módszer további előnye, hogy nem normál eloszlású adatok esetében sem ad indokolatlan mennyiségü hamis pozitív eredményt (Henseler [2021]). A PLSc-algoritmus megalkotása elött a szakemberek a kizárólag reflektív mérési modellekre épülő elemzésekben a kovarianciaalapú módszerek alkalmazását javasolták, ma azonban több szimuláció is bizonyítja, hogy ilyen esetekben a PLSc használata is elfogadható, mivel konzisztens eredményekkel jár (Dijkstra-Henseler [2015], Henseler [2012], Sarstedt et al. [2016], Aranyossy-Recskó [2021]). 


\subsection{Az eredmények újszerü bemutatása}

Az elmúlt évek PLS-PM-fejlesztései a látens/létrehozott változókat, az indikátorokat, valamint a külső és belső modell értékelésével kapcsolatos elvárásokat is érintették. A következőkben ezekről adunk áttekintést.

\subsubsection{A külső modell értékelése}

SEM alkalmazásakor a feltételezett belső (strukturális) modell értékelése mellett a külső (mérési) modell, vagyis a manifeszt változók konstrukcióinak (látens vagy létrehozott változóinak) értékelése is kulcsfontosságú. A külső modellt, amely látens változók esetében a mérési, létrehozott változók esetében a kompozit modell (Henseler [2021]), a következö szempontok szerint kell vizsgálni:

1. modellilleszkedés (model fit),

2. kompozit- (instrukció-) megbízhatóság (composite reliability),

3. konvergenciaérvényesség (convergent validity),

4. diszkriminanciaérvényesség (discriminant validity),

5. indikátormegbízhatóság (indicator reliability),

6. tartalmi érvényesség (content validity).

1. Első lépéseként a telített (saturated) modell illeszkedését vizsgáljuk, ami a külső modell érvényességét mutatja. Ezt a csak látens változókat tartalmazó modellek esetében konfirmatív faktorelemzéssel (confirmatory factor analysis, CFA), a kizárólag létrehozott változókból álló modelleknél konfirmatív kompozitelemzéssel (confirmatory composite analysis, CCA), vegyes modelleknél pedig konfirmatív kompozit-/faktorelemzéssel (confirmatory composite/factor analysis, CCFA) végezzük (Henseler [2021]). Míg a különböző elméletek vagy a korábbi eredmények alapján felépített modelleket az elemző definiálja, a telített modellben a fogalmak egymással szabadon korrelálhatnak. A koncepciók operacionalizálása mindkettő esetén megegyezik.

A modellilleszkedés vizsgálatakor az empirikus és a becsült korrelációs mátrix közötti eltéréseket mérjük. Ennek értékelése történhet például heurisztikus szabályokat követve, amikor a modellt egy elöre meghatározott küszöbérték alapján értékeljük. A PLS-PM esetén erre a standardizált reziduális négyzetes középérték (standardized root mean squared residual, SRMR) ad lehetőséget, amelynek 0 értéke tökéletes, 0 és 0,06 közötti értéke megfelelő illeszkedést jelez (Dijkstra-Henseler [2015]); a tanulmányok többségében azonban küszöbértékként inkább 0,08 szerepel. A modellilleszkedés ellenőrzésének másik módja a bootstrap-alapú illeszkedésvizsgálat, ahol minden bootsrappelt mintára meghatározzuk az illeszkedési mutatókat,

STATISZTIKAI SZEMLE, 100. ÉVFOLYAM 1. SZÁM 7-43. OLDAL DOI: 10.20311/stat2022.1.hu0007 
az SRMR-t, a (klasszikus legkisebb négyzetek módszerével számolt) duLs-t és a (távolsággal számolt) $d_{\mathrm{G}} \mathrm{t}$ (geodesic distance), majd ezek alapján az inferenciaértéket. A HI95 az az érték, amelynél a boostrappelt minták 5 százaléka nagyobb (tehát a vizsgált korrelációs mátrixok között ezeknél figyelhető meg a legnagyobb eltérés), míg a $H I 99$ az 1 százalékos határt jelöli. A Bollen-Stine-féle bootstrap-értékelés (Bollen-Stine [1992]) alapján akkor beszélhetünk megfelelő illeszkedésről, ha a modellünkből számított érték kisebb, mint $H I 95{ }^{4}{ }^{4}$

2. A konstrukciók megbizhatóságát a PLS-PM-ben hagyományosan a Cronbach- $\alpha$-val és a Dillon-Goldstein-féle $\rho_{\mathrm{A}}$ mutatóval (más néven Jöreskog- $\rho$ érték, kompozitmegbízhatóság) mérik (Ringle-Sarstedt-Straub [2012]). A legújabb ajánlások alapján a Cronbach- $\alpha$-t egyfajta alsó határértékként továbbra is érdemes figyelembe venni (Guttman [1945]), egyébként viszont Dijkstra és Henseler [2015] $\rho_{\text {A }}$ mutatójának használata javasolt. Az utóbbi küszöbértékét a szerzők 0,707-ben határozzák meg. Létrehozott változók esetében a megbízhatósági mutatók 1-et vesznek fel, így nem kell őket vizsgálni.

3. A konvergenciaérvényesség egy látens változóhoz tartozó indikátorok értékei közötti korreláció szintjét/hasonlóságát méri. Az átlagos kivonatolt variancia (average of variance extracted, AVE) az indikátorok látens változó által magyarázott varianciájának hányadát mutatja. Javasolt értéke legalább 0,5 ; ekkor az adott látens változó az indikátorok varianciájának 50 vagy annál magasabb százalékát magyarázza, az összes többi látens változó pedig ennél alacsonyabb hányadát. Más szavakkal, az elvárás az, hogy egy faktor egydimenziós legyen. Ha az első létrehozott faktor a változókészlet legalább 50 százalékát magyarázza, akkor egy esetleges második faktor már nem lehet ennél jelentősebb.

4. A diszkriminanciaérvényesség vizsgálatakor azt ellenőrizzük, hogy két látens változó, amelyek két különböző elméleti fogalmat reprezentálnak, kellően különböznek-e statisztikailag egymástól. Ennek feltétele, hogy az egyik látens változó a saját indikátorainak varianciáját jobban magyarázza, mint a másik látens változó, vagyis erősebben korrelál azokkal, mint más konstrukciók indikátoraival. Diszkriminanciaérvényességet csak látens változók esetében kell vizsgálni.

E célra korábban a Fornell-Lacker-kritériumot (Fornell-Larcker [1981]) ajánlották (Ringle-Sarstedt-Straub [2012]), amely szerint az adott látens változó $A V E$ értékének magasabbnak kell lennie, mint a kérdéses és a többi látens változó közötti korreláció négyzete (Kazár [2014]). A legújabb közlemények azonban varianciaalapú becslések esetében a konzisztens eredményt nyújtó ún. több és egy tulajdonság korrelációs arányszám (heterotrait-monotrait ratio of correlations, HTMT) alkalmazását javasolják (Henseler-Hubona-Ray [2016]). A HTMT két szempont szerint

${ }^{4}$ A HI99 megengedőbb feltétel, hisz azt vizsgáljuk, hogy a bootstrap-minták 1 százaléka nagyobb-e, mint a számított értékünk.

STATISZTIKAI SZEMLE, 100. ÉVFOLYAM 1. SZÁM 7-43. OLDAL DOI: 10.20311/stat2022.1.hu0007 
értékelhető: 1. egy elöre meghatározott küszöbérték alapján (0,90-os értéke koncepcionálisan nagyon hasonló konstrukciópárokat jelez, míg a 0,85 már inkább különbözőket; Franke-Sarstedt [2019], Henseler-Hubona-Ray [2016], Voorhees et al. [2016]) és/vagy 2. konfidenciaintervallum segítségével (a HTMT szignifikánsan kisebb-e egy meghatározott határértéknél, például 1,00-nél, 0,90-nál vagy 0,85-nál; Franke-Sarstedt [2019], Henseler-Hubona-Ray [2016]).

5. Az indikátorok, vagyis a megfigyelt változók megbizhatósága a faktorsúlyok (loadings) becsült értékével és a hozzájuk tartozó szignifikanciaszinttel mérhető. A PLS-PM-ben a faktorsúlyok becslése standardizált, ezért a becsült négyzetes faktorsúlyérték egyenlő az indikátor becsült megbízhatóságával. Az elvárás értelmében egy indikátor varianciájának több mint 50 százalékát kell, hogy a releváns látens változó magyarázza, ezért a standardizált faktorsúly esetében az elvárt küszöbérték 0,707, a $t$-érték alapján számított szignifikanciaszint pedig 5 százaléknál alacsonyabb. A legújabb szakirodalmi források alapján nemcsak a faktorsúlyokat, de a hozzájuk tartozó $t$-értéket és a szignifikanciaszintet is fontos figyelembe venni a „teljes kép” megismerése érdekében.

6. A tartalmi érvényesség mérése nem statisztikai mutatókkal történik; ehelyett az egyes konstrukciókat, illetve azt kell gondosan mérlegelni, hogy korábbi kutatásokban miként operacionalizálták az adott koncepciót, és annak vajon megfelelünk-e.

\subsubsection{A belső modell értékelése}

A belső (strukturális) modell értékelésekor a következőket vizsgáljuk:

1. teljes modellilleszkedés a becsült modell vonatkozásában,

2. útegyütthatók,

3. hatások erőssége $\left(f^{2}\right)$,

4. konstrukciók determinációs együtthatója $\left(R^{2}\right)$.

1. A modellilleszkedés elemzésekor a külső modellnél bemutatott mutatókat és szabályokat kell követni, annyi különbséggel, hogy nem a telített, hanem a becsült (estimated) modell értékeit szükséges figyelembe venni. Amennyiben annak minden konstrukciója kapcsolatban áll egymással, a telített és a becsült modell eredményei nem különböznek egymástól.

2. Az útegyütthatók vizsgálata során azt tanulmányozzuk, hogy a feltételezett hatások szignifikánsak-e. Az endogén (eredmény-/függö) és az exogén (magyarázó/független) változók közötti út együtthatója $(\beta)$ számszerúsíti, hogy ceteris paribus mekkora a függő változó várható növekedése/csökkenése a független változó egységnyi növekedésével párhuzamosan. Ez esetben az útegyütthatók iránya és abszolút értéke, illetve az is értékelhető, hogy a hatás vajon szignifikáns-e.

STATISZTIKAI SZEMLE, 100. ÉVFOLYAM 1. SZÁM 7-43. OLDAL DOI: 10.20311/stat2022.1.hu0007 
Ezek mellett javasolt a bootstrap-eredmények alapján meghatározott konfidenciaintervallumok (jellemzően a 2,5 és 97,5 százalékos percentilisek) bemutatása is. Az utóbbi tekintetében akkor beszélünk szignifikáns hatásról, ha a 0 nem esik a 95 százalékos konfidenciaintervallumba.

3. A hatások erössége is fontos információ, amely a Cohen-féle $f^{2}$-tel számszerüsíthető. E mutató a mintanagyságtól független hatások erősségét és ezáltal azok gyakorlati hasznosságát jelzi. A szakirodalom alapján (Cohen [1988]) értéke a következőképpen alakulhat:
a) $<0,02$ elhanyagolható hatás
b) $0,02-0,15$ gyenge hatás
c) $0,16-0,35$ közepes hatás
d) $0,35<$ erös hatás

Sok kutató elvárja, hogy minden hatás erös legyen, ami irreális követelmény, mivel e feltétel nem teljesülhet az összes változó tekintetében.

4. A konstrukciók determinációs együtthatója. Az $R^{2}$-mutató egy adott endogén konstrukció varianciájának azt a hányadát számszerüsíti, amelyet az exogén konstrukciók magyaráznak. Ez az érték az adott modellrész elörejelző-képességét mutatja. Egy új modell esetén az alacsony $R^{2}$ is elfogadható lehet, hiszen a mutató nagyságát, megfelelőségét a korábbi tanulmányokban szereplő determinációs együtthatókhoz képest kell értékelni. Különböző nagyságú adatkészletek felhasználásával becsült, eltérő számú független változóval rendelkező modellek összehasonlításakor a korrigált $R^{2}$-t szükséges alkalmazni (Henseler [2021]).

2. táblázat

Szószedet - a tanulmányban használt föbb idegen szavak és kifejezések

(Glossary - main foreign words and phrases used in the study)

\begin{tabular}{l|l}
\hline \multicolumn{1}{c|}{ Angol kifejezés } & \multicolumn{1}{c}{ Magyar megnevezés és rövid magyarázat } \\
\hline Auxiliary theory & $\begin{array}{l}\text { Összekötő elmélet; az indikátorok és a látens változók } \\
\text { közötti elméleti kapocs }\end{array}$ \\
\hline Average of variance extracted (AVE) & $\begin{array}{l}\text { Átlagos kivonatolt variancia; konvergenciaérvényességi } \\
\text { mutató }\end{array}$ \\
\hline Cohen's $f^{2}$ & $\begin{array}{c}\text { A minta nagyságától független mutató, amely } \\
\text { a konstrukciók közötti hatások erósségét méri }\end{array}$ \\
\hline Composite reliability & Konstrukció- (kompozit-) megbízhatóság \\
\hline Confirmatory composite analysis (CCA) & $\begin{array}{l}\text { Konfirmatív kompozit elemzés (létrehozott változók } \\
\text { esetén alkalmazandó) }\end{array}$ \\
\hline
\end{tabular}

STATISZTIKAI SZEMLE, 100. ÉVFOLYAM 1. SZÁM 7-43. OLDAL DOI: 10.20311/stat2022.1.hu0007 


\begin{tabular}{|c|c|}
\hline Angol kifejezés & Magyar megnevezés és rövid magyarázat \\
\hline Confirmatory composite/factor analysis (CCFA) & $\begin{array}{l}\text { Konfirmatív kompozit-/faktorelemzés (vegyes modellek } \\
\text { esetén alkalmazandó) }\end{array}$ \\
\hline Confirmatory factor analysis (CFA) & $\begin{array}{l}\text { Konfirmatív faktorelemzés (látens változók esetén } \\
\text { alkalmazandó) }\end{array}$ \\
\hline Content validity & Tartalmi érvényesség \\
\hline Convergent validity & Konvergenciaérvényesség \\
\hline Consistent PLS (PLSc) & Konzisztens PLS \\
\hline$d_{\mathrm{G}}$ & Két mátrix közötti különbség távolsággal számolt mutatója \\
\hline Dijkstra-Henseler's $\rho_{\mathrm{A}}$ & $\begin{array}{l}\text { A PLS-PM (partial least squares path model - parciális } \\
\text { legkisebb négyzetek módszerével becsült útmodell) } \\
\text { látens változóinak megbízhatósági mutatója }\end{array}$ \\
\hline Discriminant validity & Diszkriminanciaérvényesség \\
\hline$d_{\mathrm{ULS}}$ & $\begin{array}{l}\text { Két mátrix közötti különbség legkisebb négyzetek } \\
\text { módszerével számolt mutatója }\end{array}$ \\
\hline Emergent/forged variable & Létrehozott változó \\
\hline Estimated model & Kutató által alkotott/becsült modell \\
\hline $\begin{array}{l}\text { Heterotrait-monotrait ratio of correlations } \\
\text { (HTMT) }\end{array}$ & $\begin{array}{c}\text { Több és egy tulajdonság korrelációs arányszám; } \\
\text { diszkriminanciaérvényességi mutató }\end{array}$ \\
\hline$H I 95$ & $\begin{array}{l}\text { Bootstrap-minták megoszlásán mért } 95 \% \text {-os percentilis } \\
\text { érték }\end{array}$ \\
\hline HI99 & $\begin{array}{l}\text { Bootstrap-minták megoszlásán mért } 99 \% \text {-os percentilis } \\
\text { érték }\end{array}$ \\
\hline Indicator reliability & Indikátor megbízhatósága \\
\hline Loading & Faktorsúly \\
\hline Measurement theory & Méréselmélet \\
\hline ModeA estimation & $\begin{array}{l}\text { A PLSc-becslés ModeA változata, amely az indikátor } \\
\text { és a konstrukció közötti korrelációs együtthatón alapul }\end{array}$ \\
\hline$R^{2}$ & Konstrukciók determinációs együtthatója \\
\hline Saturated model & $\begin{array}{l}\text { Telített modell, melyben szabadon korrelálnak egymással } \\
\text { az alkotóelemek }\end{array}$ \\
\hline Standardized root mean squared residual (SRMR) & Standardizált reziduális négyzetes középérték \\
\hline
\end{tabular}

\subsection{Kutatási modell}

Online kérdőíves adatfelvételünket kényelmi mintavétellel, 2021 tavaszán hajtottuk végre, hogy tanulmányozzuk a távorvoslási szolgáltatások magyarországi igénybevételét befolyásoló tényezőket. Mintánk 238 válaszadót számlált. 
Kérdőívünkkel a távorvoslás hazai helyzetét, ismertségét, a válaszadók IKTjártasságát és a témáról alkotott véleményét térképeztük fel. A vizsgált tényezők közé beemeltük a megkérdezettek online egészségügyi müveltségét és a pandémia miatti félelmét is. Ismereteink szerint a TAM ilyen irányú bővítésére korábban még nem került sor. A más publikációkban közzétett TAM-ek és egyéb szakirodalmi források alapján épített modellünket a PLS-PM-módszertan segítségével, Adanco szoftverrel (Henseler-Dijkstra [2015]) elemeztük. (Lásd a 2. ábrát.) A korábbi fejezetekben bemutatott fejlesztéseknek köszönhetően a PLS-PM-módszertan kiválóan alkalmas az ilyen jellegü értékelésre.

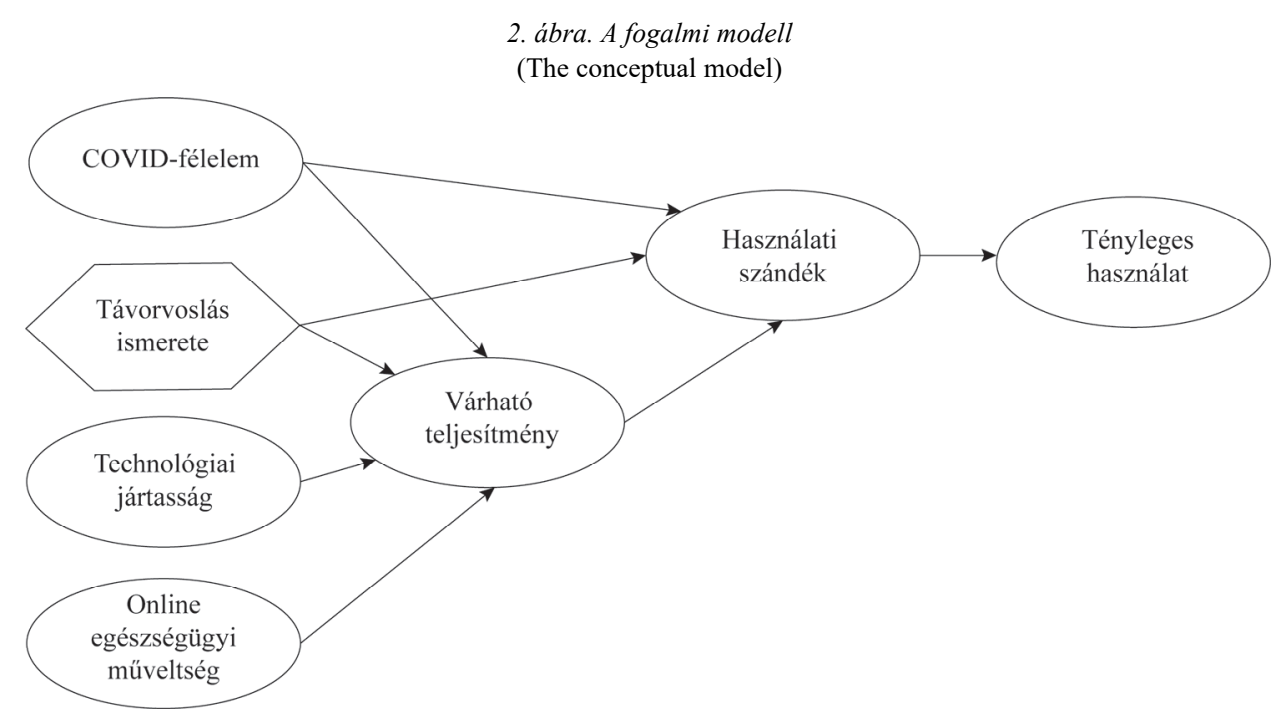

A modell konstrukcióinak leírását a 3. táblázat foglalja össze. Az online egészségügyi müveltség azt méri, hogy a válaszadó mennyire tudja egy egészségügyi probléma megoldása érdekében az online elérhető információkat hatékonyan felhasználni (Norman-Skinner [2006]). A technológiai jártasság általános dimenzió, amely a technológiához és az okoseszközökhöz való hozzáállást jelzi, a várható teljesitmény pedig arra utal, hogy az egyén milyen mértékben érzi segítségként a távorvoslás rendszerének használatát (Venkatesh et al. [2003]). A változók között egy dummy változó is található, ez a távorvoslás ismertségét méri (a „Hallott-e már erröl?” kérdés alapján) 0/1 (nem/igen) kimenettel..$^{5}$ Az általunk létrehozott tényleges használat változó az egyén által a felmérést megelőző 1 év során igénybe vett szolgáltatások számát fejezi ki. (Lásd a 3. és 4. ábrákat a 3. fejezetben.)

\footnotetext{
${ }^{5}$ Henseler [2021] ajánlása alapján a dummy változót hatszög jelöli a 2. és 6. ábrákon.
} 
A kutatásban felhasznált koncepciók és operacionalizálásuk (Concepts used in the research and their operationalization)

\begin{tabular}{l|l|l}
\hline \multicolumn{1}{c|}{ Koncepció (konstrukció) } & \multicolumn{1}{|c}{ Forrás } & \multicolumn{1}{c}{ Indikátorok száma } \\
\hline Technológiai jártasság & Saját konstrukció & 4 indikátor \\
\hline Online egészségügyi müveltség & Norman-Skinner [2006] & 8 indikátor \\
\hline Várható teljesítmény & de Veer et al. $[2015]+1$ saját indikátor & 5 indikátor \\
\hline COVID-félelem & Saját konstrukció & 2 indikátor \\
\hline Használati szándék & Venkatesh-Thong-Xu [2012] & 3 indikátor \\
\hline Távorvoslás ismerete & & Dummy változó \\
\hline Tényleges használat & Saját konstrukció & 1 indikátor \\
\hline
\end{tabular}

Megjegyzés. A koncepciók indikátoraiért lásd a Függeléket.

A 2. ábrán bemutatott modell alapján a következő hipotéziseket fogalmazzuk meg:

$H_{1}$ : A COVID-19 járvány okozta félelem pozitiv hatással van a távorvoslás várható teljesitményével kapcsolatos elvárásokra.

$\mathrm{H}_{2}$ : A COVID-19 járvány okozta félelem pozitiv hatással van a távorvoslással kapcsolatos használati szándékra.

A TAM3-ban a lehetséges exogén változók körébe a viselkedési horgonyok (például a szorongást leíró tényezők) is beletartoznak. Az általunk vizsgált kutatási terület sajátossága miatt föként a technológiai szorongás tartozik ezek közé, de a humán koronavírus terjedése miatti szorongás is, melyek a távorvoslási rendszerhez köthető teljesítményelvárást, illetve a használati szándékot egyaránt befolyásolják (Meuter et al. [2003], Venkatesh et al. [2003], Çelik [2011]). Mivel a COVID-19 miatti félelem változónk inkább a megfertőződés elkerülésével kapcsolatos, tehát megjelenik benne a távorvoslás igénybevételére vonatkozó motiváció és a megfertöződés elkerülése iránti bizakodás is, pozitív összefüggést feltételezünk (WilsonLankton [2004], Jung-Loria [2010], Bandura [1986]).

$H_{3}:$ Az online egészségügy kinálta szolgáltatások ismerete pozitívan befolyásolja a távorvoslás rendszerével kapcsolatos használati szándékot.

$\mathrm{H}_{4}$ : Az online egészségügy kinálta szolgáltatások ismerete pozitívan befolyásolja a távorvoslás rendszerének várható teljesitményét. 
Az elöbb említett viselkedési horgonyok között van az ismeretlentől való félelem is (Çelik [2011]). Ezért azt feltételezzük, hogy a távegészségügy nyújtotta lehetőségek ismertsége, vagyis az, hogy a megkérdezettek már hallottak azokról, kedvezően befolyásolja a távorvoslás várható teljesítményét és az azzal kapcsolatos használati szándékot.

$H_{5}:$ A technológiai jártasság pozitív hatással van a távorvoslás várható teljesitményére.

Melas et al. [2011] tanulmánya alapján a technológiai jártasság, vagyis az IKTismeretek kapcsolatban vannak az online egészségügyi rendszer használatának észlelt egyszerüségével. A technológiai jártasság azt jelzi, hogy az egyénnek mekkora erőfeszítésre van szüksége egy új IKT-technológia használatához. Habár ez több korábbi tanulmányban mint moderáló hatás szerepel (Venkatesh et al. [2003], Keszey-Zsukk [2017]), mi direkt hatásként tekintjük Melas et al. [2011] egészségügyi szakterületen végzett elemzésével összhangban.

$H_{6}: A z$ online egészségügyi müveltség pozitiv hatással van a távorvoslás várható teljesitményére.

Alsahafi, Gay és Khwaji [2020] az UTAUT-ból kiindulva alkották meg saját modelljüket a szaúd-arábiai elektronikus egészségügyi nyilvántartó rendszer felhasználók általi elfogadásának vizsgálatára. Eredményeik alapján feltételezzük, hogy az online egészségügyi műveltség és a távorvoslás várható teljesítménye közötti összefüggés pozitív.

$H_{7}:$ A távorvoslás várható teljesitménye pozitiv hatással van a használati szándékra.

$H_{8}:$ A távorvoslással kapcsolatos használati szándék pozitív hatással van a tényleges használatra.

Az UTAUT (Venkatesh et al. [2003]) és az UTAUT2 modellek (VenkateshThong- $X u$ [2012]), valamint ezek adaptációi a várható teljesítmény használati szándékra gyakorolt pozitív hatását bizonyítják, míg a TAM és az UTAUT a használati szándék és a tényleges magatartás közötti pozitív kapcsolatot támasztják alá (Keszey-Zsukk [2018]). $H_{7}$ és $H_{8}$ hipotéziseinket ezekre építve fogalmaztuk meg. 


\section{Eredmények}

Mintánk legfontosabb jellemzőit a 4. táblázat foglalja össze. A megkérdezettek többsége nő volt (69\%), értelmiségi (78\%), fiatal (átlagos életkoruk 34,18 év, életkoruk szórása 13,84 év), közép-magyarországi lakos (60\%), és csak kevesen (7\%) éltek közülük átlag alatti életszínvonalon.

A minta demográfiai jellemzöi $(N=238$ fö)

(Demographic characteristics of the sample $[N=238]$ )

\begin{tabular}{|c|c|c|}
\hline \multirow[b]{2}{*}{ Megnevezés } & \multicolumn{2}{|c|}{ Válaszadók } \\
\hline & $\begin{array}{c}\text { száma } \\
\text { (fö) }\end{array}$ & $\begin{array}{l}\text { megoszlása } \\
(\%)\end{array}$ \\
\hline \multicolumn{3}{|l|}{ Válaszadó neme } \\
\hline Nö & 161 & 68,8 \\
\hline Férfi & 73 & 31,2 \\
\hline \multicolumn{3}{|l|}{ Válaszadó korcsoportja } \\
\hline$\geq 25$ év & 98 & 41,9 \\
\hline $26-35$ év & 64 & 27,4 \\
\hline 36 év $\leq$ & 72 & 30,8 \\
\hline \multicolumn{3}{|l|}{ Válaszadó lakhelye } \\
\hline Föváros & 111 & 46,6 \\
\hline Megyeszékhely, megyei jogú város & 54 & 22,7 \\
\hline Város & 47 & 19,7 \\
\hline Nagyközség & 3 & 1,3 \\
\hline Község & 17 & 7,1 \\
\hline Nincs adat & 6 & 2,5 \\
\hline \multicolumn{3}{|l|}{ Válaszadó iskolai végzettsége } \\
\hline Legfeljebb szakmunkás iskola & 3 & 1,3 \\
\hline Szakközépiskola & 46 & 19,7 \\
\hline Föiskola, egyetem & 183 & 78,2 \\
\hline Egyéb & 2 & 0,9 \\
\hline \multicolumn{3}{|l|}{ Válaszadó anyagi helyzete } \\
\hline $\begin{array}{l}\text { Az alapvető dolgokat meg tudom/tudjuk vásárolni, } \\
\text { de másra nincs pénzem/pénzünk, a hó végéig éppen kitart. }\end{array}$ & 15 & 6,5 \\
\hline $\begin{array}{l}\text { Meg tudom/tudjuk vásárolni az alapvetö dolgokat, és } \\
\text { egy-két extra kiadást is megengedhetek/megengedhetünk } \\
\text { magamnak/magunknak, de félretenni nem tudok/tudunk. }\end{array}$ & 114 & 49,4 \\
\hline $\begin{array}{l}\text { Könnyedén meg tudom/tudjuk vásárolni, amire szükségem/ } \\
\text { szükségünk van, és még félre is tudok/tudunk tenni. }\end{array}$ & 102 & 44,2 \\
\hline
\end{tabular}

Megjegyzés. A megoszlásadatok kerekítés miatt nem minden esetben adják ki a 100,0 százalékot. A válaszadók demográfiai kérdések esetén feltüntetett számának összege a hiányzó értékek miatt néhol eltér 238-tól. 
A megkérdezettek 64,3 százaléka hallott már a távorvoslásról, de mindössze 31,5 százalékuk vett igénybe a felmérést megelőző 1 év során ilyen jellegủ szolgáltatásokat. Ezek közül a legnépszerübbek a következők voltak: Elektronikus Egészségügyi Szolgáltatási Tér (EESZT; 45 jelölés), e-mailes konzultáció (23 jelölés), fotóval támogatott online konzultáció (21 jelölés). Lásd a 3-5. ábrákat. ${ }^{6}$

3. ábra. A távorvoslás válaszadók általi ismertsége $(N=238$ fö)

(Awareness of e-health by respondents $[N=238]$ )

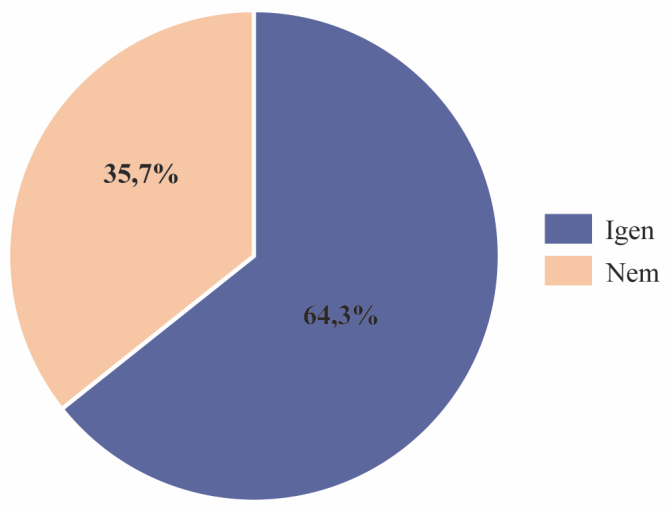

4. ábra. A felmérés elötti 1 évben távorvoslást igénybevevök megoszlása szolgáltatásszám szerint $(N=238$ fö)

(Distribution of respondents that used e-health in 1 year before the survey, by number of service $[N=238]$ )

Százalék

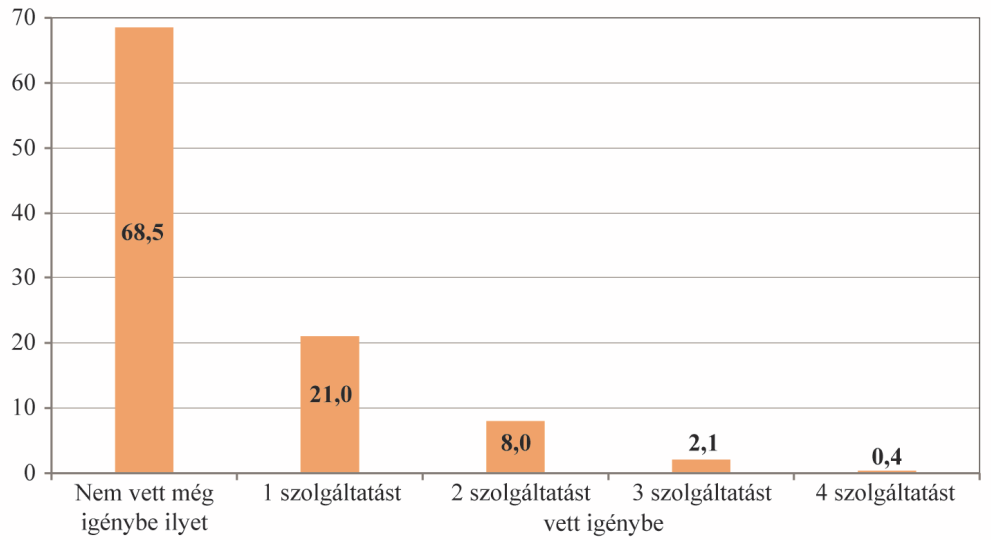

${ }^{6}$ Mivel a tanulmányunk elején elfogadott definíció alapján távorvosláson az online egészségügyi szolgáltatások és információk összességét értjük, a telefonos konzultáció (telemedicina) nem képezi vizsgálatunk tárgyát.

STATISZTIKAI SZEMLE, 100. ÉVFOLYAM 1. SZÁM 7-43. OLDAL DOI: 10.20311/stat2022.1.hu0007 
5. ábra. A felmérés elötti 1 évben távorvoslást igénybevevők száma szolgáltatástípus szerint (több válasz is lehetséges; $N=75$ fö) (Number of respondents that used e-health in 1 year before the survey, by type of service [multiple answers allowed; $N=75]$ )

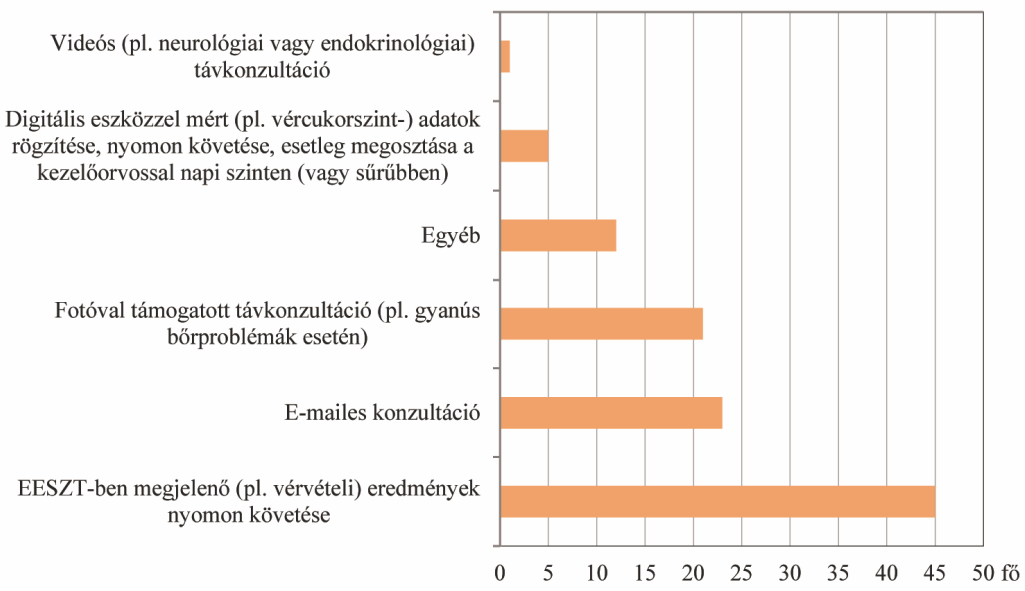

A kutatási modellünkben felhasznált konstrukciók legfontosabb leíró jellemzőit a Függelék foglalja össze. A modellek értékelését - a korábban bemutatott módon - a külső modellel kezdjük. A konfirmatív faktorelemzés alapján kapott modellilleszkedési mutatók megfelelöek. Mindhárom mutató ( $S R M R, d_{\mathrm{ULS}}$ és $\left.d_{\mathrm{G}}\right)$ a bootstrap-mintából számított 95 percentilis érték alatt található, és az SRMR értéke 0,08-nál kisebb, így az empirikus, illetve a becsült korrelációs mátrix megfelelő illeszkedést mutat. (Lásd az 5. táblázatot.)

5. táblázat

\begin{tabular}{l|c|c|c|c}
\multicolumn{4}{c}{$\begin{array}{c}\text { A konfirmativ faktorelemzés eredményei } \\
\text { (Results of the confirmatory factor analysis) }\end{array}$} \\
\hline $\begin{array}{c}\text { Mutató } \\
\text { megnevezése }\end{array}$ & Mutató értéke & $H I 95$ & $H I 99$ & Eredmény \\
\hline$S R M R$ & 0,0483 & 0,0612 & 0,0727 & Megfelelő illeszkedés \\
\hline$d_{\text {ULS }}$ & 0,6986 & 1,1221 & 1,5871 & Megfelelö illeszkedés \\
\hline$d_{\mathrm{G}}$ & 0,5575 & 1,0709 & 2,1488 & Megfelelö illeszkedés \\
\hline
\end{tabular}

A modellben használt koncepciókat reflektív mérésủ látens változókkal becsültük PLSc ModeA változatot használva. A Dijkstra-Henseler-féle $\rho_{\mathrm{A}}$, illetve a Cronbach- $\alpha$ mutatók alapján a konstrukciók megbízhatónak bizonyulnak, 
az $A V E$ igazolja a kovergenciaérvényességet, a $H T M T$-értékek pedig a diszkriminanciaérvényességet támasztják alá. (Lásd a 6 . táblázatot.) A látens változók mérésére használt indikátorok megbízhatósága ugyancsak megfelel az elvárásoknak. (Lásd a 7. táblázatot.)

6. táblázat

Diszkriminanciaérvényesség a HTMT-mutató alapján (Discriminatory validity based on the HTMT indicator)

\begin{tabular}{l|c|c|c|c|c|c}
\hline \multicolumn{1}{c|}{ Konstrukció } & 1 & 2 & 3 & 4 & 5 & 6 \\
\hline 1 Techn_jartassag & & & & & & \\
\hline 2 Eh_muveltseg & 0,3767 & & & & & \\
\hline 3 Hasznalat_szandek & 0,4148 & 0,3282 & & & & \\
\hline 4 Varhato_teljesitmeny & 0,4837 & 0,3858 & 0,8337 & & & \\
\hline 5 Covid_felelem & 0,2656 & 0,1493 & 0,5212 & 0,4725 & & \\
\hline 6 Ehealth_usage & 0,0206 & 0,0874 & 0,2401 & 0,1678 & 0,0991 & \\
\hline 7 Eh_ismeret_dummy & 0,0025 & 0,1028 & 0,1276 & 0,1856 & 0,0772 & 0,2779 \\
\hline
\end{tabular}

Megjegyzés. Itt és a további táblázatokban, techn_jartassag: technológiai jártasság; eh_muveltseg: online egészségügyi müveltség; ehealth_usage: távorvoslás tényleges igénybevétele; eh_ismeret_dummy: távorvoslás ismerete (dummy változó).

7. táblázat

A konstrukciók indikátorainak megbizhatósága (Reliability of construction indicators)

\begin{tabular}{|c|c|c|c|c|c|c|}
\hline Konstrukció indikátora & Mérési modell forrása & $\begin{array}{c}\text { Dijkstra- } \\
\text { Henseler-féle } \\
\rho_{\mathrm{A}}\end{array}$ & $\begin{array}{c}\text { Cronbach-féle } \\
\alpha\end{array}$ & $A V E$ & Faktorsúly & $t$-érték \\
\hline Techn_jartassag_1 & Saját konstrukció & 0,868 & 0,868 & 0,622 & 0,776 & 7,959 \\
\hline Techn_jartassag_2 & & & & & 0,796 & 8,094 \\
\hline Techn_jartassag_3 & & & & & 0,798 & 9,428 \\
\hline Techn_jartassag_4 & & & & & 0,785 & 9,506 \\
\hline Varhato_teljesitmeny_1 & $\begin{array}{l}\text { de Veer et al. }[2015] \\
+1 \text { saját indikátor }\end{array}$ & 0,942 & 0,937 & 0,648 & 0,700 & 11,750 \\
\hline Varhato_teljesitmeny_2 & & & & & 0,780 & 18,254 \\
\hline Varhato_teljesitmeny_3 & & & & & 0,782 & 18,870 \\
\hline Varhato_teljesitmeny_4 & & & & & 0,801 & 20,582 \\
\hline Varhato_teljesitmeny_5 & & & & & 0,750 & 16,834 \\
\hline Hasznalat_szandek_1 & $\begin{array}{l}\text { Venkatesh-Thong-Xu } \\
{[2012]}\end{array}$ & 0,881 & 0,880 & 0,711 & 0,821 & 23,941 \\
\hline
\end{tabular}

(A táblázat folytatása a következö oldalon) 


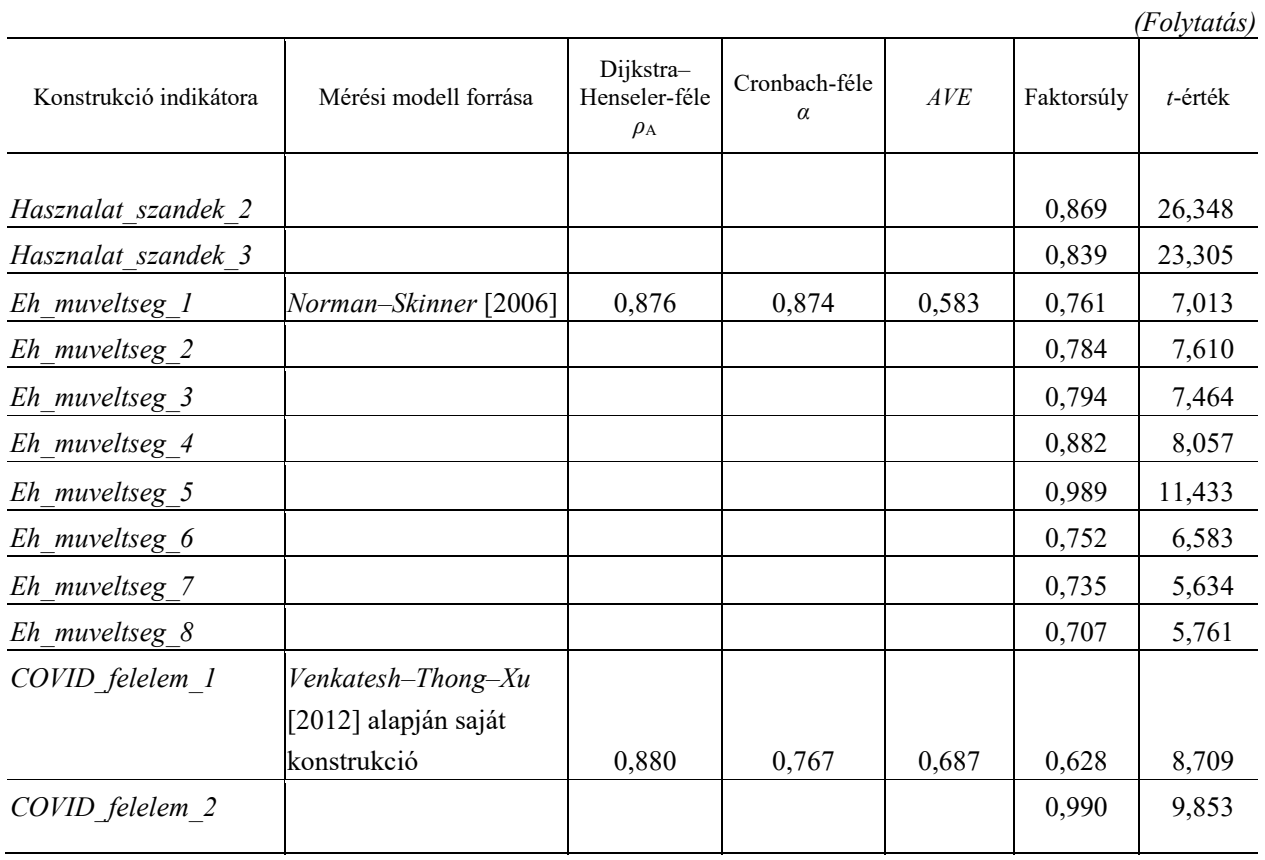

Megjegyzés. A modellben használt koncepciókat reflektív mérésű látens változókkal becsültük meg PLSc ModeA változatot használva. A konstrukciók indikátoraiért lásd a Függeléket.

Az általunk kidolgozott modell illeszkedése minden értékelési szempont alapján megfelelő, így a strukturális modell is vizsgálható.

A felállított hipotézisek közül egy kivételével mindet igazoltunk, vagyis a feltételezett pozitív hatások 5 százalékos szinten szignifikánsak. (Lásd a 8. táblázatot.)

A távorvoslási rendszerrel kapcsolatos használati szándékra, amelynek magyarázott varianciahányada 71,6 százalék, a legerősebb hatást a várható teljesítmény gyakorolja. A koronavírustól való félelem ugyancsak pozitív összefüggést mutat a használati szándékkal, ám ez gyengének tekinthető $\left(f^{2}=0,072\right)$, hiába szignifikáns a várható teljesítményen keresztül kifejtett indirekt hatása $\left(\beta_{\text {indirekt }}=0,261\right)$. A pandémia miatti aggódás és a távorvoslás várható teljesítménye közötti kapcsolat is pozitív és számottevő $\left(f^{2}=0,190\right)$, vagyis minél inkább tart valaki a fertőzéstől, annál inkább hisz abban, hogy a távegészségügy hatékony, ideális megoldást jelent. A várható teljesítményre gyakorolt hatás nagyságát tekintve a pandémia okozta félelmet a technológiai jártasság követi $\left(f^{2}=0,146\right)$. Az IKT iránt nyitottabb, azt a mindennapjaik részének tekintő válaszadók nagyobb elvárást támasztanak a távorvoslással szemben. A távegészségügyi rendszerrel kapcsolatos tájékozottság is számottevően, pozitívan befolyásolja a megkérdezettek elvárásait, viszont nem fejt ki szignifikáns közvetlen hatást a használati szándékra. Hasonlóan fontos szerepet tölt 
be e téren az online egészségügyi müveltség is, hisz közvetett módon - a várható teljesítményen keresztül - ez is növeli a használati szándékot. A korábbi tanulmányokban közölt eredményekhez hasonlóan a mieink is alátámasztják a használati szándék és a tényleges használat közötti pozitív szignifikáns hatást, bár ennek az endogén változónak jelentéktelen a magyarázott varianciahányada $\left(R^{2}=5,8 \%\right)$.

8. táblázat

A hipotézisvizsgálat eredményei és a modell megbizhatósága a szignifikáns hatások esetében (Hypothesis test results and reliability of the model [only significant effects are presented])

a) Közvetlen és közvetett hatások (Direct and indirect effects)

\begin{tabular}{|c|c|c|c|c|c|}
\hline \multirow[t]{2}{*}{ Kapcsolat } & \multirow[t]{2}{*}{$\beta$} & \multirow[t]{2}{*}{$p$-érték } & \multirow[t]{2}{*}{$t$-érték } & \multicolumn{2}{|c|}{$\begin{array}{c}\text { Bootstrap- } \\
\text { konfidenciaintervallum } \\
\text { percentilise }\end{array}$} \\
\hline & & & & $2,5 \%$ & $97,5 \%$ \\
\hline \multicolumn{6}{|c|}{ Közvetlen hatás } \\
\hline Techn_jartassag $\rightarrow$ varhato_teljesitmeny & 0,322 & 0,003 & 3,465 & 0,128 & 0,490 \\
\hline Eh_muveltseg $\rightarrow$ varhato_teljesitmeny & 0,205 & 0,006 & 2,757 & 0,068 & 0,356 \\
\hline Hasznalat_szandek $\rightarrow$ ehealth_usage & 0,241 & 0,000 & 3,942 & 0,122 & 0,358 \\
\hline Varhato_teljesitmeny $\rightarrow$ hasznalat_szandek & 0,760 & 0,000 & 14,851 & 0,652 & 0,854 \\
\hline COVID_felelem $\rightarrow$ hasznalat_szandek & 0,161 & 0,010 & 2,577 & 0,045 & 0,287 \\
\hline COVID_felelem $\rightarrow$ varhato_teljesitmeny & 0,344 & 0,000 & 5,063 & 0,218 & 0,481 \\
\hline 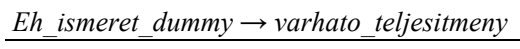 & 0,142 & 0,013 & 2,484 & 0,026 & 0,250 \\
\hline \multicolumn{6}{|c|}{ Közvetett hatás } \\
\hline Techn_jartassag $\rightarrow$ hasznalat_szandek & 0,245 & 0,001 & 3,300 & 0,095 & 0,388 \\
\hline Techn_jartassag $\rightarrow$ ehealth_usage & 0,059 & 0,008 & 2,660 & 0,019 & 0,106 \\
\hline Eh_muveltseg $\rightarrow$ hasznalat_szandek & 0,156 & 0,007 & 2,672 & 0,050 & 0,276 \\
\hline Eh_muveltseg $\rightarrow$ ehealth_usage & 0,038 & 0,040 & 2,056 & 0,009 & 0,080 \\
\hline Varhato_teljesitmeny $\rightarrow$ ehealth_usage & 0,183 & 0,000 & 3,880 & 0,091 & 0,273 \\
\hline COVID_felelem $\rightarrow$ hasznalat_szandek & 0,261 & 0,000 & 5,090 & 0,164 & 0,365 \\
\hline COVID_felelem $\rightarrow$ ehealth_usage & 0,102 & 0,002 & 3,129 & 0,046 & 0,172 \\
\hline Eh_ismeret_dummy $\rightarrow$ hasznalat_szandek & 0,108 & 0,015 & 2,429 & 0,020 & 0,195 \\
\hline Eh_ismeret_dummy $\rightarrow$ ehealth_usage & 0,026 & 0,044 & 2,011 & 0,004 & 0,055 \\
\hline
\end{tabular}

b) Endogén változó (Endogenous variable)

\begin{tabular}{l|c}
\hline \multicolumn{1}{c|}{ Endogén változó } & $R^{2}$ \\
\hline Hasznalat_szandek & 0,716 \\
\hline Varhato_teljesitmeny & 0,419 \\
\hline Ehealth_usage & 0,058 \\
\hline
\end{tabular}


c) Modellilleszkedési mutató

(Modell goodness of fit)

\begin{tabular}{l|c|c}
\hline \multicolumn{1}{c|}{ Mutató megnevezése } & Mutató értéke & $H I 95$ \\
\hline$S R M R$ & 0,051 & 0,063 \\
\hline$d_{\mathrm{ULS}}$ & 0,783 & 1,206 \\
\hline$d_{\mathrm{G}}$ & 0,575 & 1,078 \\
\hline
\end{tabular}

d) Hatáserősség

(Strength of effect)

\begin{tabular}{l|c}
\hline \multicolumn{1}{c|}{ Hatáserősség } & $f^{2}$ \\
\hline Techn_jartassag $\rightarrow$ varhato_teljesitmeny & 0,146 \\
\hline Eh_muveltseg $\rightarrow$ varhato_teljesitmeny & 0,061 \\
\hline Hasznalat_szandek $\rightarrow$ ehealth_usage & 0,061 \\
\hline Varhato_teljesitmeny $\rightarrow$ hasznalat_szandek & 1,611 \\
\hline COVID_felelem $\rightarrow$ hasznalat_szandek & 0,072 \\
\hline COVID_felelem $\rightarrow$ varhato_teljesitmeny & 0,190 \\
\hline Eh_ismeret_dummy $\rightarrow$ varhato_teljesitmeny & 0,034 \\
\hline
\end{tabular}

6. ábra. A távorvoslás igénybevételét magyarázó tényezök kapcsolata (Relationship between the factors explaining the use of e-health)

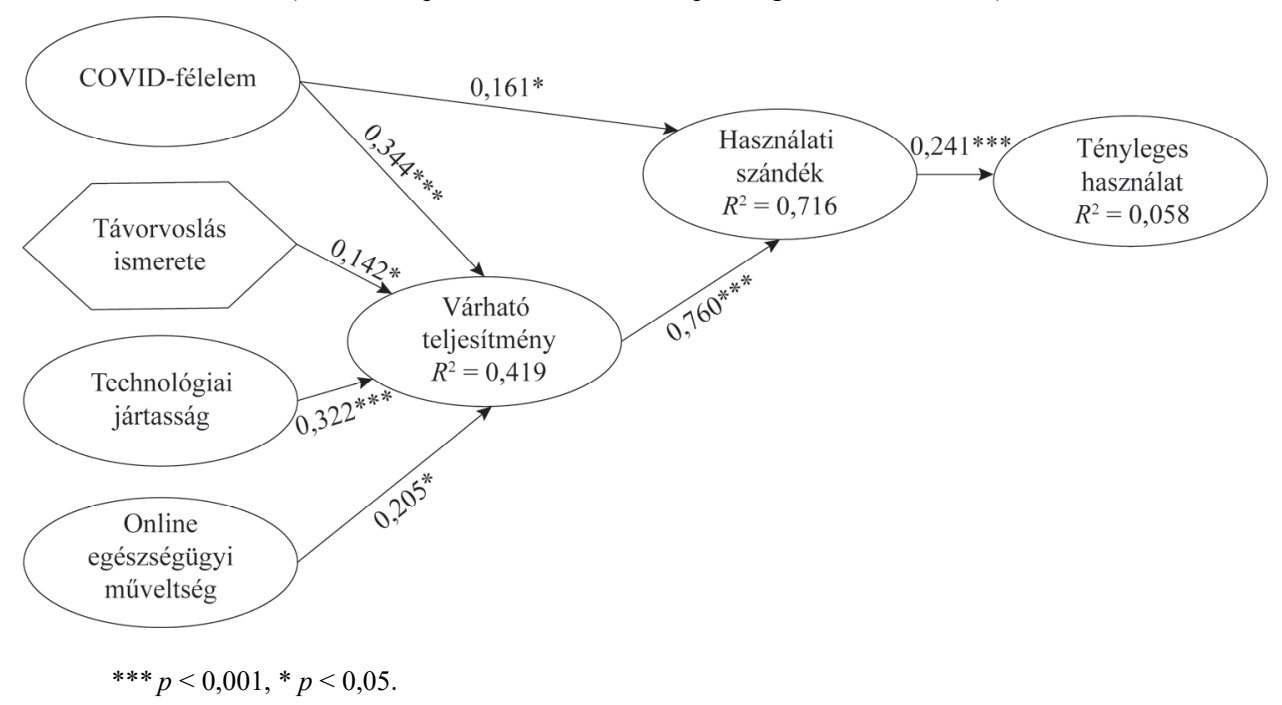

STATISZTIKAI SZEMLE, 100. ÉVFOLYAM 1. SZÁM 7-43. OLDAL DOI: 10.20311/stat2022.1.hu0007 


\section{4. Összefoglaló}

Az új rendszerek, online technológiák elfogadásának folyamata a 2000-es évek óta foglalkoztatja az akadémiai kutatókat (Venkatesh-Davis [2000], Venkatesh et al. [2003], Keszey-Zsukk [2017]), mivel a felhasználók által alkalmazott technológiák köre egyre bővül. Az e-egészségügy közel 10 éve kutatott terület (HoldenKarsh [2010], Liu [2010], Ahlan-Ahmad [2015], Abdullah et al. [2016], Bahlol et al. [2018]), melynek magyarországi elterjedése és használata a COVID-19 járvány hatására felgyorsult. Az orvosok és pácienseik elvárásainak ismerete nemcsak a távorvoslás nyújtotta szolgáltatások sikeres igénybevételét tekintve, de a koronavírussal szembeni küzdelemben is kulcsfontosságú. Tanulmányunkban a hazai, páciensoldali felhasználók véleményét kívántunk feltárni egy korábbi tanulmányok (Bandura [1986], Meuer et al. [2003], Venkatesh et al. [2003], Çelik [2011], Melas et al. [2011], Alsahafi-Gay-Khwaji [2020]) alapján alkotott PLS-PM-modell segítségével, amely konstrukcióként a távorvoslás rendszerének teljesítményével szembeni elvárást, az arra vonatkozó használati szándékot és a tényleges használatot tartalmazza.

Eredményeink alapján a feltételezett hatások közül egy kivételével mindegyik teljesül (lásd a 6. ábrát), és így a távorvoslás várható teljesítményét, illetve a hozzá kapcsolódó használati szándék változót - különösen az utóbbit - megfelelően tudjuk magyarázni. A távegészségügy tényleges használatának magyarázatára azonban további kutatásokra van szükség.

A várható teljesítmény változóra a koronavírus okozta félelem van a legerösebb hatással, vagyis minél inkább tart valaki a megfertőződéstől, és bízik a távorvoslásban, annál jobban hisz abban, hogy a távegészségügy hatékony és ideális megoldást jelenthet. Az érintésmentesség kiemelt szerepet játszik a COVID-19 járvány idején (például a vásárlások, házhozszállítások stb. vonatkozásában), ezért az ez iránti törekvés is tükröződhet ebben a hatásban. Érdemes lenne azonban a jövöben azt is megvizsgálni, hogy a különböző szigorítások (például maszkviselési vagy védettségiigazolvány-kötelezettség, négyzetméteralapú létszámkorlátozás) tükrében miként alakul ez az összefüggés.

A második tényező, amely a távorvoslás teljesítményéhez kötődő elvárásokat leginkább befolyásolja, a technológiai jártasság. Minél inkább nyitott ugyanis egy egyén az új technológiák iránt, és tekinti azokat a mindennapjai részének, annál inkább nőnek a távorvoslással kapcsolatos elvárásai. Ezt az összefüggést számos egyéb területen is vizsgálták már. A tanulmányok többségében mint moderáló hatás jelenik meg (Venkatesh et al. [2003], Keszey-Zsukk [2017]), Melas et al. [2011] megállapításai alapján azonban mi direkt hatásnak vettük, és e feltételezésünket (a pozitív kapcsolatot) igazolni is tudtuk. A társadalom IKT-ismeretének bövítése tehát e téren is fontos szerepet játszik, különösen, ha az online egészségügy teremtette lehetőségekre

STATISZTIKAI SZEMLE, 100. ÉVFOLYAM 1. SZÁM 7-43. OLDAL DOI: 10.20311/stat2022.1.hu0007 
gondolunk az idős korosztály egészségmegörzésében, kezelésében. Mindezek miatt javítani kell a lakosság online egészségügyi műveltségét, illetve meg kell ismertetni velük a távorvoslás fogalmát, szolgáltatásait. Pozitív kapcsolatot mutattunk ki a távegészségüggyel kapcsolatos tájékozottság és a használati szándékot fokozni képes teljesítményelvárások között is.

A használati szándékot leginkább a várható teljesítmény tudja befolyásolni; ezért e hatás erősítése érdekében érdemes hangsúlyozni a távegészségügyi szolgáltatások által nyújtott várható és észlelhető előnyöket. A COVID-19 miatti félelem a használati szándékot motiváló tényezőként is megjelenik.

Eredményeink alapján levonhatjuk azt a következtetést, hogy a távorvoslási szolgáltatások jelenleginél fokozottabb igénybevételét átfogó oktatókampányokkal lehet elősegíteni. Az IKT iránti nyitottság erősítése már évek óta célkitüzésként jelenik meg különböző fejlesztési programokban, de speciális edukációs projektekre is szükség van e téren. Továbbá kiemelt szerepet kell szánni az online egészségügyi műveltség ${ }^{7}$ javításának, valamint a távorvoslás népszerüsítésének.

Végezetül említést kell tennünk a kutatásunk néhány korlátjáról is. A felmérés során önkényes mintavételt alkalmaztunk, amelynek következtében mintánk föleg átlagos/átlag feletti életszínvonalon élő fiatalokból állt. Eredményeink értékelésekor ezért erröl nem szabad megfeledkeznünk. A további elemzésekben érdemes lenne elkülöníteni a magán- és a közegészségügyet is.

Modellünk egyik kiindulópontjaként az UTAUT szolgált, amelyben az életkor mint moderáló változó jelenik meg. Ezért kívánatos lenne a jövőben az adatfelvételt nemre, korra, illetve régióra reprezentatív mintán megismételni. Újabb kutatási irány lehet a tényleges technológiahasználat más jellegű mérése vagy a magyarázó változók körének bővítése is. Habár tanulmányunk írásakor az adatfelvétel óta kevesebb mint 6 hónap telt el, a környezet ez időszak alatt jelentősen megváltozott: az EESZT használata - amely már kutatásunkkor is a legnépszerübb ilyen jellegü szolgáltatástípusnak számított - a COVID-oltásra vonatkozó időpontfoglalások, a védettségi igazolvánnyal kapcsolatos ügyintézés, az antitestvizsgálatok eredményeinek feltöltése stb. következtében kiterjedtebbé vált. Ezért érdekes lenne a felmérés óta történt változásokat is tanulmányozni.

\footnotetext{
${ }^{7}$ Információkeresés egészségügyi témákban, információforrások szavahihetőségének megítélése, döntések azokra építése stb.
}

STATISZTIKAI SZEMLE, 100. ÉVFOLYAM 1. SZÁM 7-43. OLDAL DOI: 10.20311/stat2022.1.hu0007 


\section{Függelék}

\begin{tabular}{|c|c|c|c|}
\hline \multirow{2}{*}{ Konstrukció, indikátor } & \multirow{2}{*}{ Kérdés } & \multicolumn{2}{|c|}{ Minta } \\
\hline & & átlaga & szórása \\
\hline \multicolumn{4}{|c|}{ Technológiai jártasság } \\
\hline Techn_jartassag_l & Gyakran használok okoseszközöket. & 6,26 & 1,272 \\
\hline Techn_jartassag_2 & $\begin{array}{l}\text { A digitális technológiák alkalmazása nem okoz számomra } \\
\text { kihívást. }\end{array}$ & 5,71 & 1,539 \\
\hline Techn_jartassag_3 & Könnyen tanulok meg új technológiákat. & 5,44 & 1,557 \\
\hline Techn_jartassag_4 & A modern technológia a mindennapjaim része. & 6,00 & 1,442 \\
\hline \multicolumn{4}{|c|}{ Várható teljesítmény } \\
\hline Varhato_teljesitmeny_1 & $\begin{array}{l}\text { Az online kapcsolatfelvétel egészségügyi szakemberekkel } \\
\text { kényelmes. }\end{array}$ & 5,63 & 1,553 \\
\hline Varhato_teljesitmeny_2 & $\begin{array}{l}\text { Az online kapcsolatfelvétel egészségügyi szakemberekkel } \\
\text { egyszerübbé teszi számomra, hogy akkor lépjek velük } \\
\text { kapcsolatba, amikor csak szeretnék. }\end{array}$ & 5,35 & 1,657 \\
\hline Varhato_teljesitmeny_3 & $\begin{array}{l}\text { Az online kapcsolatfelvétel egészségügyi szakemberekkel } \\
\text { megfelelöen tud müködni. }\end{array}$ & 4,47 & 1,466 \\
\hline Varhato_teljesitmeny_4 & $\begin{array}{l}\text { Az online kapcsolatfelvétel egészzégügyi szakemberekkel } \\
\text { ehetővé teszi számomra, hogy helytöl függetlenül kapjak orvosi } \\
\text { ellátást. }\end{array}$ & 5,48 & 1,593 \\
\hline Varhato_teljesitmeny_5 & $\begin{array}{l}\text { Az online kapcsolatfelvétel egészségügyi szakemberekkel } \\
\text { megbízható eredményt biztosít. }\end{array}$ & 4,26 & 1,456 \\
\hline \multicolumn{4}{|c|}{ Használati szándék } \\
\hline Hasznalat_szandek_1 & Amikor elérhető lesz számomra a távorvoslás, ki fogom próbálni. & 5,44 & 1,597 \\
\hline Hasznalat_szandek_2 & $\begin{array}{l}\text { Amikor elérhető lesz számomra a távorvoslás, rendszeresen } \\
\text { igénybe fogom venni. }\end{array}$ & 4,58 & 1,733 \\
\hline Hasznalat_szandek_3 & $\begin{array}{l}\text { Amikor elérhető lesz számomra a távorvoslás, át fogok állni a } \\
\text { használatára. }\end{array}$ & 4,33 & 1,765 \\
\hline
\end{tabular}

(A táblázat folytatása a következö oldalon) 


\begin{tabular}{|c|c|c|c|}
\hline Konstrukció, indikátor & Kérdés & \multicolumn{2}{|c|}{ Minta } \\
\hline \multicolumn{4}{|c|}{ Online egészségügyi műveltség } \\
\hline Eh_muveltseg_1 & $\begin{array}{l}\text { Tudom, milyen egészségügyi források állnak rendelkezésemre az } \\
\text { interneten. }\end{array}$ & 4,50 & 1,614 \\
\hline Eh_muveltseg_2 & $\begin{array}{l}\text { Tudom, hol találok hasznos egészségügyi információkat az } \\
\text { interneten. }\end{array}$ & 4,69 & 1,587 \\
\hline Eh_muveltseg_3 & $\begin{array}{l}\text { Tudom, hogyan találok hasznos egészségügyi információkat az } \\
\text { interneten. }\end{array}$ & 4,79 & 1,617 \\
\hline Eh_muveltseg_4 & $\begin{array}{l}\text { Tudom, hogyan használhatom az internetet az egészséggel } \\
\text { kapcsolatos kérdéseim megválaszolására. }\end{array}$ & 4,78 & 1,563 \\
\hline Eh_muveltseg_5 & $\begin{array}{l}\text { Tudom, hogyan használhatom fel az interneten talált } \\
\text { egészségüggyel kapcsolatos információkat a segítségemre. }\end{array}$ & 4,58 & 1,534 \\
\hline Eh_muveltseg_6 & $\begin{array}{l}\text { Meg tudom ítélni az interneten található egészségügyi források } \\
\text { minőségét. }\end{array}$ & 4,60 & 1,624 \\
\hline Eh_muveltseg_7 & $\begin{array}{l}\text { Meg tudom különböztetni az alacsony és magas/jó minőségű } \\
\text { internetes forrásokat az egészségüggyel kapcsolatban. }\end{array}$ & 4,74 & 1,574 \\
\hline Eh_muveltseg_8 & $\begin{array}{l}\text { Magabiztosan használom fel az interneten talált információkat } \\
\text { egészségügyi döntések meghozatalakor. }\end{array}$ & 4,27 & 1,665 \\
\hline \multicolumn{4}{|c|}{ COVID-19 miatti félelem } \\
\hline COVID_felelem_1 & $\begin{array}{l}\text { A távorvoslás használata csökkenti a félelmemet azzal } \\
\text { kapcsolatban, hogy koronavírus által megfertőződök, vagy } \\
\text { másokat megfertőzök. }\end{array}$ & 4,74 & 1,873 \\
\hline COVID_felelem_2 & $\begin{array}{l}\text { Kevésbé érzem magam paranoiásnak, ha a távorvoslást } \\
\text { használom a COVID-19 járvány idején. }\end{array}$ & 4,40 & 1,908 \\
\hline
\end{tabular}

\section{Irodalom}

Abdullah, A. - Liew, S. M. - Hanafi, N. S. - NG, C. J. - Lai, P. S. - Chia, Y. C. - Loo, C. K. [2016]: What influences patients' acceptance of a blood pressure telemonitoring service in primary care? A qualitative study. Patient Preference and Adherence. Vol. 10. January. pp. 99-106. https://doi.org/10.2147/PPA.S94687

Ahlan, A. R. - AhMAD, B. I. [2015]: An overview of patient acceptance of health information technology in developing countries: A review and conceptual model. International Journal of Information Systems and Project Management. Vol. 3. No. 1. pp. 29-48. https://doi.org/10.12821/ijispm030102

Allen, A. - Whitten, P. - Maheu, M. M. [2001]: E-health, Telehealth, and Telemedicine: A Guide to Startup and Success. John Wiley \& Sons. New York. 
Alsahafi, Y. A. - GAY, V. - KhWAJI, A. A. [2020]: Factors affecting the acceptance of integrated electronic personal health records in Saudi Arabia: The impact of e-health literacy. Health Information Management: Journal of the Health Information Management Association of Australia. 28 November. https://doi.org/10.1177\%2F1833358320964899

ARANYossy M. - RECSKÓ M. [2021]: Konzisztens PLS-modellezés alkalmazása egy lehetséges közösségi kriptovaluta felhasználói elfogadásának vizsgálatában. Statisztikai Szemle. 99. évf. 9. sz. 844-873. old. https://doi.org/10.20311/stat2021.9.hu0844

ARIEF, M. - HAI, N. T. T. - SARANTO, K. [2013]: Barriers to and advantages of e-health from the perspective of elderly people: A literature review. Finnish Journal of EHealth and EWelfare. Vol. 5. Nos. 2-3. pp. 50-56.

BAHLOL, R. - NADRI, H. - AfShAR, H. L. - TIMPKA, T. [2018]: A systematic review of the technology acceptance model in health informatics. Applied Clinical Informatics. Vol. 9. No. 3. pp. 604-634. https://doi.org/10.1055/s-0038-1668091

BandurA, A. [1986]: Social Foundations of Thought and Action: A Social Cognitive Theory. Prentice-Hall. Englewood Cliffs.

Benitez, J. - Henseler, J. - CAstillo, A. - Schuberth, F. [2020]: How to perform and report an impactful analysis using partial least squares: Guidelines for confirmatory and explanatory IS research. Information - Management. Vol. 57. No. 2. Article No. 103168. https://doi.org/10.1016/j.im.2019.05.003

Blackwell, G. - Gordon, B. [2008]: The future of IT in healthcare. Informatics for Health and Social Care. Vol. 33. No. 4. pp. 211-326. https://doi.org/10.1080/17538150802598860

BolLEN, K. A - Stine, R. A. [1992]: Bootstrapping goodness-of-fit measures in structural equation models. Sociological Methods \& Research. Vol. 21. No. 2. pp. 205-229. https://doi.org/10.1177/0049124192021002004

Borges, U. - KubiaK, T. [2016]: Continuous glucose monitoring in type 1 diabetes: Human factors and usage. Journal of Diabetes Science and Technology. Vol. 10. Issue 3. pp. 1-7. https://doi.org/10.1177/1932296816634736

Butcher, L. [2016]: Shifting sources of patient access. Physician Leadership Journal. Vol. 3. No. 4. p. 6.

ÇELIK, H. [2011]: Influence of social norms, perceived playfulness and online shopping anxiety on customers' adoption of online retail shopping: An empirical study in the Turkish context. International Journal of Retail \& Distribution Management. Vol. 39. No. 6. pp. 390-413. https://doi.org/10.1108/09590551111137967

Сно, Н. - Кiм, Y. - Kiм, J. [2010]: An acceptance model for an internet protocol television service in Korea with prior experience as a moderator. The Service Industries Journal. Vol. 30. No. 11. pp. 1883-1901. https://doi.org/10.1080/02642060802627178

Cohen, J. [1988]: Statistical Power Analysis for the Behavioural Sciences. $2^{\text {nd }}$ Edition. Laurence Erlbaum Associates. Mahwah.

Cranen, K. - Veld, R. H. - Ijzerman, M. - Vollenbroek, H. M. [2011]: Change of patients' perceptions of telemedicine after brief use. Telemedicine and e-Health. Vol. 17. No. 7. pp. 530-535. https://doi.org/10.1089/tmj.2010.0208

Dahl, A. J. - Milne, G. R. - Peltier, J. W. [2019]: Digital health information seeking in an omnichannel environment: A shared decision-making and service-dominant logic perspective.

STATISZTIKAI SZEMLE, 100. ÉVFOLYAM 1. SZÁM 7-43. OLDAL DOI: 10.20311/stat2022.1.hu0007 
Journal of Business Research. Vol. 125. No. 1. pp. 840-850. https://doi.org/10.1016/ j.jbusres.2019.02.025

DARAGó L. J. - Jung Z. - Ispán F. - Bendes R. - DinYA E. [2013]: A telemedicina előnyei és hátrányai. Orvosi Hetilap. 154. évf. 30. sz. 1167-1171. old. https://doi.org/10.1556/ OH.2013.29664

DAVIS, F. D. - BAgOzZI, R. P. - WARShAw, P. R. [1989]: User acceptance of computer technology: A comparison of two theoretical models. Management Science. Vol. 35. No. 8. pp. $903-1028$. https://doi.org/10.1287/mnsc.35.8.982

DAvis, F. D. [1986]: A Technology Acceptance Model for Empirically Testing New End-User Information Systems: Theory and Results. Massachusetts Institute of Technology. Cambridge.

DAVIS, F. D. [1989]: Perceived usefulness, perceived ease of use, and user acceptance of information technologies. MIS Quarterly. Vol. 13. No. 3. pp. 319-340. https://doi.org/10.2307/ 249008

Demiris, G. - Finkelstein, S. M. - Speedie, S. M. [2001]: Considerations for the design of a web-based clinical monitoring and educational system for elderly patients. Journal of the American Medical Informatics Association. Vol. 8. No. 5. pp. 468-472. https://doi.org/ 10.1136/jamia.2001.0080468

De Veer, A. J. - Peeters, J. M. - Brabers, A. E. - Schellevis, F. G. - Rademakers, J. J. J. FRANCKE, A. L. [2015]: Determinants of the intention to use e-health by community dwelling older people. BMC Health Services Research. Vol. 15. No. 1. pp. 1-9. https://doi.org/10.1186/s12913-015-0765-8

Dijkstra, T. K. - Henseler, J. [2015]: Consistent and asymptotically normal PLS estimators for linear structural equations. Computational Statistics \& Data Analysis. Vol. 81. November. pp. 10-23. https://doi.org/10.1016/j.csda.2014.07.008

EYSENBACH, G. [2001]: What is e-health? Journal of Medical Internet Research. Vol. 3. No. 2. Article No. 11720962. https://doi.org/10.2196/jmir.3.2.e20

Európai KözössÉgek Bizottsága [2008]: A Bizottság Közleménye az Európai Parlamentnek, a Tanácsnak, az Európai Gazdasági és Szociális Bizottságnak és a Régiók Bizottságának a távorvoslásról a betegek, az egészségügyi ellátórendszerek és a társadalom javára. $\operatorname{COM}(2008) 689$ végleges. November 4. Brüsszel. https://eur-lex.europa.eu/legalcontent/HU/TXT/PDF/?uri=CELEX:52008DC0689\&from=HU

Fornell, C. (ed.) [1982]: A Second Generation of Multivariate Analysis: Measurement and Evaluation. Praeger. New York.

FoRNELL, C. - LARCKER, D. F. [1981]: Evaluating structural equation models with unobservable variables and measurement error. Journal of Marketing Research. Vol. 18. No. 1. pp. 39-50. https://doi.org/10.2307/3151312

FrAnKe, G. - SARSTEDT, M. [2019]: Heuristics versus statistics in discriminant validity testing: A comparison of four procedures. Internet Research. Vol. 29. No. 3. pp. 430-447. https://doi.org/10.1108/IntR-12-2017-0515

FüsTÖS L. [2009]: A sokváltozós adatelemzés módszerei. MTA Szociológiai Kutatóintézete Társadalomtudományi Elemzések Akadémiai Műhelye. Budapest. 
Gagnon, M.-P. - Desmartis, M. - Labrecque, M. - Car, J. - Pagliari, C. - Pluye, P. Frémont, P. - GAgnON, J. - TREMBLAy, N. - LÉGARÉ, F. [2012]: Systematic review of factors influencing the adoption of information and communication technologies by healthcare professionals. Journal of Medical Systems. Vol. 36. No. 1. pp. 241-277. https://doi.org/10.1007/s10916-010-9473-4

Garavand, A. - Mohseni, M. - Asadi, H. - Etemadi, M. - Moradi-Joo, M. - Moosavi, A. [2016]: Factors influencing the adoption of health information technologies: A systematic review. Electron Physician. Vol. 8. No. 8. pp. 2713-2718. https://oi.org/10.5001/omj.2020.85ar

GeFEn, D. - Rigdon, E. E. - StRAub, D. W. [2011]: An update and extension to SEM guidelines for admnistrative and social science research. Management Information Systems Quarterly. Vol. 35. No. 2. pp. III-XII. https://doi.org/10.2307/23044042

Guttman, L. [1945]: A basis for analyzing test-retest reliability. Psychometrika. Vol. 10. No. 4. pp. 255-282. https://doi.org/10.1007/BF02288892

Henseler, J. - DiJKstra, T. K. [2015]: ADANCO 2.0. Composite Modeling GmbH. Kleve.

Henseler, J. - Hubona, G. - RAY, P. A. [2016]: Using PLS path modeling in new technology research: Updated guidelines. Industrial Management \& Data Systems. Vol. 116. No. 1. pp. 2-20. https://doi.org /10.1108/IMDS-09-2015-0382

HENSELER, J. [2012]: Why generalized structured component analysis is not universally preferable to structural equation modeling. Journal of the Academy of Marketing Science. Vol. 40. No. 3. pp. 402-413. https://doi.org/10.1007/s11747-011-0298-6

HENSELER, J. [2017]: Bridging design and behavioral research with variance-based structural equation modeling. Journal of Advertising. Vol. 46. No. 1. pp. 178-192. https://doi.org/10.1080/00913367.2017.1281780

Henseler, J. [2021]: Composite-Based Structural Equation Modeling: Analyzing Latent and Emergent Variables. The Guilford Press. New York.

HoLDEN, R. J. - KARSH, B. T. [2010]: The technology acceptance model: Its past and its future in health care. Journal of Biomedical Informatics. Vol. 43. No. 1. pp. 159-172. https://doi.org/10.1016/j.jbi.2009.07.002

Hollander, J. E. - CARR, B. G. [2020]: Virtually perfect? Telemedicine for COVID-19. New England Journal of Medicine. Vol. 382. No. 18. pp. 1679-1681. https://doi.org/10.1056/NEJMp2003539

Hu, P. J. - CHAU, P. Y. - SHENG, O. R. - TAM, K. Y. [1999]: Examining the technology acceptance model using physician acceptance of telemedicine technology. Journal of Management Information Systems. Vol. 16. No. 2. pp. 91-112. https://doi.org/10.1080/07421222.1999. 11518247

INCZE N. - Pesuth T. [2020]: E-Health: digitalizálódik az egészségügy? Köz-gazdaság. 15. évf. 4. sz. 247-250. old. https://doi.org/10.14267/RETP2020.04.20

JuLESz M. [2020]: A telemedicina és a COVID-19-világjárvány. Információs Társadalom. XX. évf. 3. sz. 27-38. old. https://dx.doi.org/10.22503/inftars.XX.2020.3.2

Jung, M.-L. - LORIA, K. [2010]: Acceptance of Swedish e-health services. Journal of Multidisciplinary Healthcare. Vol. 3. November. pp. 55-63. https://dx.doi.org/10.2147/JMDH.S9159

KAZÁR K. [2014]: A PLS-útelemzés és alkalmazása egy márkaközösség pszichológiai érzetének vizsgálatára. Statisztikai Szemle. 92. évf. 1. sz. 35-52. old. 
KEMÉNY I. [2015]: A versenytársak csak egy kattintásra vannak. Az újravásárlási és továbbajánlási szándék alakulása különböző e-kereskedelmi kategóriákban. Doktori értekezés. Budapesti Corvinus Egyetem. Budapest. https://doi.org/10.14267/phd.2015030

KEMÉNY I. [2017]: Az elektronikusszolgáltatás-minőség értékelése a pénzügyi szolgáltatások online vásárlása esetében. Vezetéstudomány. 48. évf. 2. sz. 15-29. old. https://doi.org/ 10.14267/VEZTUD.2017.02.02

KESZEY T. - ZsUKK J. [2017]: Az új technológiák fogyasztói elfogadása. A magyar és nemzetközi szakirodalom áttekintése és kritikai értékelése. Vezetéstudomány. 48. évf. 10. sz. 38-47. old. https://doi.org/10.14267/VEZTUD.2017.10.05

Kun Zs. - KulHAVI N. - KEMÉNY I. [2021]: Helyzetkép a SEM módszertan alkalmazásáról a hazai tudományos üzleti folyóiratokban. In: Mitev, A. - Csordás, T. - Horváth, D. - Boros, K. (eds.): Post-traumatic Marketing: Virtuality and Reality - Proceedings of the EMOK 2021 International Conference. Corvinus University of Budapest. Budapest. p. 87.

KwankAm, Y. S. [2004]: What e-health can offer. Bulletin of the World Health Organization. Vol. 82. No. 10. pp. 800-802.

LAI, T.-Y. - LARSON, E. L. - RockOFF, M. L. - BAKKEN, S. [2008]: User acceptance of HIV TIDEStailored interventions for management of depressive symptoms in persons living with HIV/AIDS. Journal of American Medical Informatics Association. Vol. 5. No. 2. pp. 217-226. https://doi.org/10.1197/jamia.M2481

Legrisa, P. - Inghamb, J. - Collerettec, P. [2003]: Why do people use information technology? A critical review of the technology acceptance model. Information \& Technology. Vol. 40. No. 3. pp. 191-204. http://dx.doi.org/10.1016/S0378-7206(01)00143-4

LiU, V. - CAELli, W. - ChEN, Y. M. [2013]: Using a public key registry for improved trust and scalability in national e-health systems. International Journal of E-Health and Medical Communications. Vol. 4. No. 4. pp. 66-83. http://doi.org/10.4018/ijehmc.2013100105

LIU, X. [2010]: Empirical testing of a theoretical extension of the technology acceptance model: An exploratory study of educational Wikis. Communication Education. Vol. 59. No. 1. pp. 52-69. https://doi.org/10.1080/03634520903431745

LuPTON, D. [2013]: Quantifying the body: Monitoring and measuring health in the age of mHealth technologies. Critical Public Health. Vol. 23. No. 4. pp. 393-403. https://doi.org/10.1080/ 09581596.2013 .794931

MCLENDON, K. [2000]: E-commerce and HIM: Ready or not, here it comes. Journal of AHIMA. Vol. 71. No. 1. pp. 22-23.

Melas, C. D. - Zampetakis, L. A. - Dimopoulou, A. - Moustakis, V. [2011]: Modeling the acceptance of clinical information systems among hospital medical staff: An extended TAM model. Journal of Biomedical Informatics. Vol. 44. No. 4. pp. 553-564. https://doi.org/10.1016/j.jbi.2011.01.009

Meuter, M. L. - Ostrom, A. L. - Bitner, M. J. - Roundtree, R. I. [2003]: The influence of technology anxiety on consumer use and experience with self-service technologies. Journal of Business Research. Vol. 56. No. 11. pp. 899-906. https://doi.org/10.1016/S01482963(01)00276-4

NAGy Á. - KemÉnY I. - SzÜCS K. - SimOn J. - KeHL D. [2019]: A véleményformáló magatartás mint másodrendủ látens változó modellezése PLS-alapú strukturális egyenletek 
módszerével. Statisztikai Szemle. 97. évf. 9. sz. 827-854. old. https://doi.org/ 10.20311/stat2019.9.hu0827

Norman, C. D. - SkinNER, H. A. [2006]: eHEALS: The ehealth literacy scale. Journal of Medical Internet Research. Vol. 8. No. 4. e27. https://doi.org/10.2196/jmir.8.4.e27

NovaK, T. P. - HofFMAn, D. L. - ADAM, D. [2003]: The influence of goal-directed and experiential activities on online flow experiences. Journal Consumer Psychology. Vol. 13. No. 1. pp. 3-16. https://doi.org/10.1207/153276603768344744

Pagliari, C. - Sloan, D. - Gregor, P. - Sullivan, F. - Detmer, D. - Kahan, J. P. - Oortwijn, W. - Macgillivray, S. [2005]: What is eHealth (4): A scoping exercise to map the field. Journal of Medical Internet Research. Vol. 7. No. 1. e9. https://doi.org/10.2196/jmir.7.1.e9

PAppot, N. - TAARnhøJ, G. A. - РАрPOT, H. [2020]: Telemedicine and e-health solutions for COVID-19: Patients' perspective. Telemedicine and e-Health. Vol. 26. No. 7. pp. 847-849. https://doi.org/10.1089/tmj.2020.0099

Pavlou, P. A. [2003]: Consumer acceptance of electronic commerce: Integrating trust and risk with the technology acceptance model. International Journal of Electronic Commerce. Vol. 7. No. 3. pp. 101-134. https://doi.org/10.1080/10864415.2003.11044275

Peng, G. - Dey, D. - LAHIRI, A. [2014]: Healthcare IT adoption: An analysis of knowledge transfer in socioeconomic networks. Journal of Management Information Systems. Vol. 31. No. 3. p. 7. https://doi.org/10.1080/07421222.2014.994672

Pinzon-PereZ, H. - ZelinSKI, C. [2016]: The role of teleconferences in global public health education. Global Health Promotion. Vol. 23. No. 2. pp. 38-44. https://doi.org/10.1177/ 1757975914567180

Reichenbach, H. [1956]: The Direction of Time. University of California Press. Berkeley.

Ringle, C. - SARStedt, M. - Straub, D. [2012]: Editor's comments: A critical look at the use of PLS-SEM in 'MIS Quarterly'. MIS Quarterly. Vol. 36. No. 1. pp. III-XIV. https://doi.org/10.2307/41410402

Sarstedt, M. - Hair, J. F. - Ringle, C. M. - Thiele, K. O. - Gudergan, S. P. [2016]: Estimation issues with PLS and CBSEM: Where the bias lies! Journal of Business Research. Vol. 69. No. 10. pp. 3998-4010. https://doi.org/10.1016/j.jbusres.2016.06.007

Shigemura, J. - Ursano, R. J. - Morganstein, J. C. - Kurosawa, M. - BenedeK, D. M. [2020]: Public responses to the novel 2019 coronavirus (2019-nCoV) in Japan: Mental health consequences and target populations. Psychiatry and Clinical Neuroscience. Vol. 74. No. 4. pp. 281-282. https://doi.org/10.1111/pcn.12988

Ting, D. S. W. - CARIN, L. - DZAU, V. - Wong, T. Y. [2020]: Digital technology and COVID-19. Nature Medicine. Vol. 26. No. 4. pp. 459-461. https://doi.org/10.1038/s41591-020-0824-5

Tsion, H. - TeBEJE, J. K. [2020]: Applications of e-health to support person-centered health care at the time of COVID-19 pandemic. Telemedicine and e-Health. Vol. 27. No. 2. pp. 150-158. https://doi.org/10.1089/tmj.2020.0201

Venkatesh, V. - Bala, H. [2008]: Technology Acceptance Model 3 and a research agenda on interventions. Decision Sciences. Vol. 39. No. 2. pp. 273-315. https://doi.org/10.1111/ j.1540-5915.2008.00192.x 
VenKATESh, V. - DAVIS, F. D. [2000]: A theoretical extension of the technology acceptance model: Four longitudinal field studies. Management Science. Vol. 45. No. 2. pp. 186-204. https://doi.org/10.1287/mnsc.46.2.186.11926

Venkatesh, V. - Morris, M. G. - Gordon, B. D. - DaVis, F. D. [2003]: User acceptance of information technology: Toward a unified view. MIS Quarterly. Vol. 27. No. 3. pp. 425-478. https://doi.org/10.2307/30036540

Venkatesh, V. - Thong, J. Y. L. - XU, X. [2012]: Consumer acceptance and use of information technology: Extending the unified theory of acceptance and use of technology. MIS Quarterly. Vol. 36. No. 1. pp. 157-178. https://doi.org/10.2307/41410412

Voorhees, C. M. - Brady, M. K. - Calantone, R. - Ramirez, E. [2016]: Discriminant validity testing in marketing: An analysis, causes for concern, and proposed remedies. Journal of the Academy of Marketing Science. Vol. 44. No. 1. pp. 119-134. https://doi.org/10.1007/s11747-015-0455-4

Wallace, L. G. - SheEtZ, S. D. [2014]: The adoption of software measures: A technology acceptance model [TAM] perspective. Information \& Management. Vol. 51. Issue 2. pp. 249-259. https://doi.org/10.1016/j.im.2013.12.003

WiLSON, E. V. - LANKTON, N. K. [2004]: Modeling patients' acceptance of provider-delivered e-health. Journal of the American Medical Informatics Association: JAMIA. Vol. 11. No. 4. pp. 241-248. https://doi.org/10.1197/jamia.M1475

Wind, T. R. - RiJkeboer, M. - ANDERSSON, G. - RiPER, H. [2020]: The COVID-19 pandemic: The 'black swan' for mental health care and a turning point for e-health. Internet Interventions. Vol. 20. April. Article No. 1003172. https://doi.org/10.1016/ j.invent.2020.100317

Yarbrough, A. K. - Smith, T. B. [2007]: Technology acceptance among physicians: A new take on TAM. Medical Care Research and Review. Vol. 64. No. 6. pp. 650-672. https://doi.org/10.1177/1077558707305942

Zhou, X. - Snoswell, C. L. - Harding, L. E. - Bambling, M. - Edirippulige, S. - Bai, X. SMith, A. C. [2020]: The role of telehealth in reducing the mental health burden from COVID-19. Telemedicine Journal and e-Health: The Official Journal of the American Telemedicine Association. Vol. 26. No. 4. pp. 377-379. https://doi.org/10.1089/ tmj.2020.0068 